\title{
Analysis of secondary school quantum physics curricula of 15 different countries: Different perspectives on a challenging topic
}

\author{
H. K. E. Stadermann, ${ }^{1, *}$ E. van den Berg, ${ }^{2}$ and M. J. Goedhart ${ }^{1}$ \\ ${ }^{1}$ Department of science education and communication, University of Groningen, \\ Nijenborgh 9, 9747 AG Groningen, Netherlands \\ ${ }^{2}$ ELAN, Department of Teacher Development, University of Twente, \\ Postbus 217, 7500 AE Enschede, Netherlands
}

(Received 13 February 2019; published 22 May 2019)

\begin{abstract}
Secondary school level quantum physics (QP) courses have recently been implemented in the national curricula of many countries. QP gives opportunities to acquaint students with more recent physics and its applications and to discuss aspects of the nature of science. Research has shown that QP is a challenging area for students. Because the inclusion of QP in national curricula is rather new in most countries, it is interesting to compare QP curricula from these countries to make the choices by curriculum designers visible. In this study, we provide a detailed overview of QP courses from fifteen countries. We collected and analyzed official curriculum documents to identify key items present in most curricula. Our inventory identifies a shared current core curriculum of QP which contains the following seven main categories: discrete atomic energy levels, interactions between light and matter, wave-particle duality, de Broglie wavelength, technical applications, Heisenberg's uncertainty principle, and the probabilistic nature of QP. We also found differences in the focus of the listed topics of certain countries, which indicate different views on teaching QP and might inspire curriculum designers struggling with QP. For instance, challenging items like QP interpretations or epistemological aspects of QP are taught only in a few countries. Although research suggests that epistemological aspects help students to comprehend novel QP concepts, many countries do not explicitly include these in the curriculum. We provide reasons and suggestions for this.
\end{abstract}

DOI: 10.1103/PhysRevPhysEducRes.15.010130

\section{INTRODUCTION}

Quantum physics (QP) is not all about calculating, and there are diverse reasons why it deserves a place in secondary school curricula. First of all, QP is crucial for our current scientific worldview; students should get the chance to learn this in high school and not be limited to 19th-century physics [1-3]. Furthermore, QP brought us devices like lasers, solar cells, and microchips that are indispensable for modern life and there is an increasing number of research fields where QP offers new possibilities (e.g., DNA decoding with tunneling, quantum computers, or cryptography). School physics that aims to trigger students' interests with real-life contexts and futureoriented research may better replace some outdated topics in favor of quantum technology. And finally, popular science topics like quantum teleportation, parallel worlds, or quantum computers appeal to the imagination. Similar to

*h.k.e.stadermann@rug.nl

Published by the American Physical Society under the terms of the Creative Commons Attribution 4.0 International license. Further distribution of this work must maintain attribution to the author(s) and the published article's title, journal citation, and DOI.
Einstein's theory of relativity, QP fascinates scientists as well as students [4-7], and educators should not miss the chance to give physics a more attractive image.

The weird and fascinating, almost mythical, image makes QP appealing, though challenging to teach. In contrast to most classical physics topics, we cannot find a consistent visualization for quantum phenomena. QP offers students new views on physical reality, which conflict with earlier learned classical concepts such as the nature of particles, locality, and determinism. Scientists still discuss how-and if at all-QP should be interpreted. In the opinion of some physicists the interpretation controversy is needless [8] or even a scandal [9]. Additionally, instructors have different opinions on discussing philosophical aspects with students. For example, Alonso [10] stated, "My motto is: Learn first what quantum mechanics is good for, and afterwards analyze its epistemological implications." However, recent research shows that epistemological aspects can motivate and help students to understand QP conceptually [11,12]. Moreover, there are instructors who, indeed, use different interpretations of QP to teach students aspects of the nature of science (NOS) $[4,13,14]$. In the views of these educators, the disagreement on interpretations is an excellent example of science in 
action: competing scientific theories can exist next to each other as long as there is no evidence favoring one theory over another one [15-18]. Thus, for secondary education philosophical and historical aspects of QP are not only advocated to enhance students' conceptual understanding but also to serve the more general goal to develop their view on the NOS.

The reason for this research was the controversial introduction of QP in the Dutch national high school curriculum in 2014. Teachers and textbook authors had doubts if secondary school students would be capable of understanding QP concepts at the necessary level of abstraction. The general purpose of the introduction, the selection of content, and the nature of exam questions were subjects of discussion. In this situation, it is valuable to look at the practice of other countries. A similar occasion in 2005, when QP was introduced in Portuguese secondary school physics, led to a general analysis of official curricula of ten countries: Portugal, Spain, France, Italy, United Kingdom, Denmark, Sweden, Finland, Australia, and Canada [19]. It turned out that, at that time, only half of the analyzed countries addressed pure QP themes like uncertainty or duality. The curriculum documents of the other countries only mentioned topics like the quantization of energy levels in the context of atomic physics, which can also be explained with semiclassical models. Remarkably, this study did not include countries like Germany and Austria, which have a long history of teaching QP at the secondary level. In recent years the content of official secondary school physics curricula also changed in the countries mentioned in the Portuguese study. At present, most upper secondary physics curricula contain more aspects of QP. We are not aware of more recent and detailed overviews of QP on the secondary school level. Even one of the best known international studies on advanced science courses in upper secondary school Trends in International Mathematics and Science Study (TIMSS advanced) [20] only gives a short overview of some aspects of QP in the curricula of nine countries. Therefore, the purpose of this study is threefold:

(i) to give a structured overview of QP topics in upper secondary school curricula of different countries.

(ii) to identify similarities and differences between the content of QP in these curricula and to give an account on the possible rationale of the common and the distinguishing components.

(iii) to investigate how $\mathrm{QP}$ is placed in a perspective of learning about NOS in different educational systems.

\section{THEORETICAL FRAMEWORK}

Our research is about curriculum, quantum physics, and the nature of science. In the following, we present some theoretical and pragmatic outlines and definitions for this article.

\section{A. Curriculum documents}

In this study, we collected and analyzed curriculum documents from various countries. Although "curriculum" is a familiar term in educational literature, there is no consensual definition of this term. Curriculum has been defined in terms of learner experiences [21] or as a plan for teaching. This latter might be a list of aims or objectives for learning or a more detailed description of all planned activities in classrooms, including teaching materials and assessment [22]. Van den Akker [23] differentiates five levels of curriculum: international or comparative ("supra" level), nation and state or system ("macro" level), school and institution ("meso" level), classroom ("micro" level), and individual and personal ("nano" level). This grouping is useful for our research; all examined documents stem from the macro level and have an official status such as a national or federal curriculum which is legislated by the government or prescribed by a Department of Education and describes the intended learning outcomes on a specific level. In scientific literature about different curriculum perspectives, these documents are also categorized as the "written" or "formal" representation of the "intended curriculum" $[24,25]$.

In this paper, we will further use the term "curriculum documents" to refer to all official written sources we used for answering our research questions. If a document gives very detailed specifications, we might alternatively use the term "syllabus" or "exam syllabus." We only use these specifying documents when they belong to the macro level, so that they are binding legal guidelines for the textbook or exam developers and thus practically mandatory to be followed by educators.

Curriculum documents cannot be compared directly, because these documents serve different purposes in disparate school systems. Especially in countries with compulsory final written examinations like the Netherlands, France, and several German federal states, the syllabi are very detailed. They precisely describe which skills and what content items are essential for the exam. In these countries, the curriculum documents serve as a practical source of information for students, teachers, and textbook authors. In other countries, the national curriculum documents describe the learning outcomes in more general terms.

Indeed there are more reasons for the diversity of the analyzed curriculum documents: the traditions of a country, its general conception of education and the expectations of society affect the content and style of a formal curriculum. However, it is beyond the scope of this research to go into these complex backgrounds. A general classification of the function of a curriculum document can be made by the national examination practices. The kind of examination is usually defined in the curriculum documents and is a significant indication for the particular role and context of each document. We distinguish centrally set school 
leaving exams and school-based exams. The former are standardized written final exams that are administered to large populations of students so that results can be compared across the country or state. School-based exams are written or oral final exams, locally developed at the school level or by individual teachers, giving them the opportunity to tune the exam with the curriculum document, but evidently, standardization is difficult.

\section{B. Quantum physics in secondary schools}

Some time ago, physics undergraduates would not take a course called "quantum mechanics" until their third year at university. To understand the mathematical formalism of quantum mechanics students first should have mastered partial differential equations, complex numbers, and linear operators in Hilbert spaces. This kind of sophisticated math is not taught in high school, and, consequently, courses on the secondary school level cannot focus on a rigorous mathematical description of QP. Therefore, we prefer the more general term quantum physics, emphasizing that the focus is on the "big ideas" rather than the mathematical formalisms. The content of QP courses for secondary schools is comparable to introductory QP courses at the college level for nonphysics majors. These courses mostly cover some historical developments of quantum theory with key experiments and the following central themes: photoelectric effect, wave and particle behavior, de Broglie wavelength, double slit interference, probability interpretation, uncertainty principle [26,27]. To meet our definition of $\mathrm{QP}$ in secondary schools, it is essential that the curriculum covers at least one of the following topics that are related to the fundamental principles: matter waves (e.g., interference of electrons or the de Broglie relation), wave-particle duality, the probabilistic nature of QP (i.e., QP can only give statistical predictions of measurement outcomes), Heisenberg's uncertainty principle, or entanglement. A country is not included in our overview if the official curriculum document solely contains topics such as line spectra of gases, discrete energy levels in an atom or light emitting diodes (LED). These topics are related to QP, but the first two can be explained with a semiclassical planetary (Bohr) model of the atom, and the LED appears in some syllabi only as an electronic component without any QP context.

\section{Nature of science}

For more than a century scientists and educational authorities have promoted the idea that teachers should not only present results of scientific research as "facts" but that students ought to learn how research is done and how scientific knowledge develops [28]. Currently, this is referred to as teaching the nature of science, which is a term open to many interpretations. Even though the epistemological question as to what the nature of science precisely is, remains deeply philosophical, we want to use the term NOS in the current understanding in secondary education. It refers to what students should learn about the processes that are involved in scientific work and methods scientists use. Knowledge about the NOS is seen as an indispensable part of students' scientific literacy within the development of their critical thinking [29,30]. In the context of global challenges such as the impact of climate change and the need for sustainable energy use, knowledge about NOS becomes increasingly relevant for all citizens. Understanding how science works is a prerequisite for distinguishing between scientific and nonscientific claims. In the last decennium, NOS has, therefore, become an essential part of science curricula and policy documents in many countries [31]. What exactly teachers should teach and how it can be done successfully is the subject of discussion and research on its own [32-35].

Science education research shows that several NOS aspects are particularly relevant for learning QP. Without an understanding of the function and limitations of models, students might stick to the classical idea that particles behave like downsized billiard balls [36,37]. QP concepts like superposition, interference and Heisenberg's uncertainty relation are not compatible with this model of a particle. A student who believes that science provides absolute truth —and this belief could be caused by previous physics lessons or textbooks [38]—will have problems appreciating the different interpretations of QP. In practice, many students will get to know only one interpretation of QP, namely, the instructor's favorite interpretation. Research in quantum physics teaching and learning shows that teachers' choice of an interpretation affects students' understanding of QP [39] and that this choice should be explicitly explained to the students [40].

To identify NOS aspects in curriculum documents we use elements from two studies that focus on the practical use of NOS in education. The first one is McComas' and Olsen's [41] analysis of science education standards documents and the second one is a Delphi study that Osborne et al. [42] performed with 23 international experts to find a consensus about which NOS ideas should be taught. To limit the scope of this research, we only focused on some NOS aspects from these studies that could be relevant in the context of teaching QP. We also searched for history of science as a learning goal in the curriculum documents because many scholars advocate including the history of science into lessons to develop informed NOS views of students $[43,44]$ and QP is often introduced via historical experiments. Table I shows how NOS aspects are essential for the development of concepts in QP.

\section{METHODOLOGY}

Our work consists of three main steps. First, we sought macrolevel secondary school curriculum documents which cover aspects of QP. Next, we scrutinized these curriculum documents with the focus on QP and NOS. To get an 
TABLE I. Aspects of nature of science and history of science in quantum physics.

\begin{tabular}{|c|c|c|}
\hline Code & NOS and history aspects & Example of relevance for $\mathrm{QP}$ \\
\hline N1 & $\begin{array}{l}\text { Methodology (e.g., } \\
\text { experiments and hypothesis) }\end{array}$ & $\begin{array}{l}\text { The methodology used in classical physics (relation between experiment and theory) } \\
\text { apply as well in QP. Additionally, thought experiments were an essential means to } \\
\text { discuss fundamental concepts in the developing of QP and eventually led to various } \\
\text { quantum entanglement experiments. }\end{array}$ \\
\hline N2 & The role of scientific models & $\begin{array}{l}\text { For some situations, it is appropriate to use the model of a wave for quantum objects; in } \\
\text { other situations the model of classical particles is more helpful. A model only serves to } \\
\text { show some aspects of phenomena. (In QP lessons, students experience different models } \\
\text { of light or matter.) }\end{array}$ \\
\hline N3 & Tentativeness of science & $\begin{array}{l}\text { Even though physics can explain many phenomena, the history of physics including QP } \\
\text { shows that science is tentative. To the long-held hypothesis that light is a wave, Einstein } \\
\text { added the photon hypothesis of light as a possible explanation of the photoelectric } \\
\text { effect. This was one of the many steps in a historical paradigm shift which eventually } \\
\text { led to the development of QP. The current existence of different interpretations of QP } \\
\text { shows that scientists question existing models and interpretations and that this is an } \\
\text { ongoing process. }\end{array}$ \\
\hline N4 & Creativity in science & $\begin{array}{l}\text { To invent famous thought experiments scientists had to be creative and only with thinking } \\
\text { out-of-the-box new quantum experiments can be developed. Many scientists want to } \\
\text { find out if the wave function is more than just a conceptual tool. Therefore, they develop } \\
\text { creative interpretations of QP. }\end{array}$ \\
\hline N5 & Controversies in science & $\begin{array}{l}\text { The famous discussions between Bohr and Einstein were important for the development } \\
\text { of QP. Currently, there is still discussion about different interpretations of QP. Only in } \\
\text { an open atmosphere without dominating ideologies science can freely develop. }\end{array}$ \\
\hline N6 & History of science & $\begin{array}{l}\text { More than in other parts of physics the history of QP is regarded as relevant for education. } \\
\text { Historical experiments illustrate why scientists had to change their mechanical } \\
\text { world view. (For students, this can give science a more human image and it brings } \\
\text { theory to life.) }\end{array}$ \\
\hline
\end{tabular}

overview of how QP can be taught at the secondary level, we identified a list of QP items that are mentioned in different curricula. We also checked which of the aspects from Table I are described in the curriculum documents. Once we had an overview of which curriculum items are present in each document we analyzed the similarities and differences of the QP curriculum and NOS aspects.

\section{A. Selection of curriculum documents}

Although QP is taught in secondary schools in many countries, there is no straightforward way to find countries where QP is part of the mandatory curriculum. Furthermore, relevant curriculum documents are naturally written in the countries' languages and not always easily accessible. The most comprehensive international studies for secondary school education, Programme for International Student Assessment (PISA) and TIMSS, compare educational achievement of students not older than fifteen years, and QP is usually not included in the science curriculum for this age group. Even "TIMSS advanced" about students in the final year of secondary school enrolled in special advanced mathematics and physics programs, covers only some aspects of QP. Moreover, the most recent report from 2015 only contains brief information about the intended physics curriculum of nine participating countries: France, Italy, Lebanon, Norway, Portugal, Russian Federation, Slovenia, Sweden, and United States [20].

In order to find official curriculum documents from countries where QP is taught, we identified physics education research literature by using the keywords secondary school and quantum, or high school and quantum in databases (ERIC, Google Scholar, WorldCat) since 1996. Additional scanning of the reference lists of the articles found in this initial search and eliminating articles with no physics education context yielded a total of 76 documents dealing with QP in secondary education. The majority of these articles originated from European countries, in particular, Germany (28 articles), Italy (11 articles), and Norway (10 articles). The documents were about teaching and learning QP in advanced secondary physics courses, innovative QP teaching materials or teacher training programs. The QP content of the research articles concerned the following themes: (i) fundamental principles, which emphasize the difference between classical physics, (ii) real or simulated experiments and phenomena to visualize concepts or to show real-world applications, (iii) QP used in the context of atomic theory (iv), the wave function or other mathematical representations, and (v) philosophical aspects of QP. When the authors of an article mentioned the 
source of a written curriculum, we checked whether the documents were still up to date. In other cases, we contacted authors to get access to the most recent official curriculum documents. This search finally led to 37 current official curriculum documents originating from fifteen different countries plus the International Baccalaureate (IB) diploma program. Some countries have more than one official curriculum document (details are explained in Appendix B). Although the IB cannot be linked to one country, we added the IB diploma program to our research because of its international and exemplary character [45].

Countries without accessible national curriculum documents for upper secondary schools or without QP, as we defined it above, are not included in our overview. Additionally, countries might not be listed because no published research in English emerged from our initial literature search. Accordingly, it is not our intention to give a complete overview of all countries around the world in which QP is taught in secondary schools. Instead, we want to analyze which content is typically used to introduce this challenging topic in different educational systems.

\section{B. Identification and clustering of QP items}

We scrutinized the curriculum documents and indicated text fragments related to $\mathrm{QP}$, as defined above. To give a complete overview of what students are expected to know about QP in different countries we derived a list of more than 30 QP items from the syllabuses. By clustering items that belong together into one synoptic term, we reduced a long list with details from all curricula to a manageable summary. For example, the term "matter wave quantitative" combines content items like "Wave character of electrons; relationship between momentum and wavelength according to de Broglie; qualitative experiments with the electron diffraction tube, quantitative data analysis of double-slit or lattice experiments" (Bavaria, Germany) or "calculations with the de Broglie wavelength" (Netherlands). The guiding principle for developing the final list was that it should be as detailed as necessary and as short as possible. After a check of the list by three experts (a professor of theoretical physics and two physics education researchers), we arrived at a list of 17 QP topics that were mentioned in more than one curriculum document. We double checked all documents, and in case of doubt, we asked a local expert to check the coding and our findings. We do not claim that these topics are fundamental or cannot be condensed more, but it gives a detailed and at the same time manageable overview of which aspects of QP are treated in secondary schools. Our final list of $17 \mathrm{QP}$ curriculum topics is shown in Table II.

We ordered the QP items in a way that is convenient for our purpose: From "blackbody radiation" (Q1) to "wave-particle duality" (Q5) the list roughly follows the chronological historical development of QP, which is also a standard order in many curricula. From Q6 onwards the position of a topic represents its frequency, across all documents, from the most to the least often mentioned ones.

TABLE II. List of items for the comparison and analysis of different curriculum documents.

\begin{tabular}{|c|c|}
\hline Code & Description \\
\hline Q1 & Black body radiation; \\
\hline Q2 & Bohr atomic model (i.e., electrons on certain allowed orbits), also if it is only used for hydrogen; \\
\hline Q3 & Discrete energy levels in atoms (not orbits) and absorption line spectra of gases as a result of it; \\
\hline Q4 & Interaction between light and matter (e.g., photoelectric effect or the Compton effect); \\
\hline Q5 & $\begin{array}{l}\text { Wave-particle duality, an example of Bohr's complementarity principle (often introduced with the double slit experiment or with } \\
\text { a Mach-Zehnder interferometer); }\end{array}$ \\
\hline Q6 & $\begin{array}{l}\text { Matter waves, quantitative (calculations with de Broglie wavelength of particles) the de Broglie wavelength might be used to } \\
\text { determine if a situation should be regarded as a quantum system; }\end{array}$ \\
\hline Q7 & Technical applications (e.g., scanning electron microscope SEM, semiconductors, LED, laser); \\
\hline Q8 & Uncertainty (Heisenberg's principle); \\
\hline Q9 & Probabilistic nature of QP (statistical predictions are possible for the results of measurements); \\
\hline Q10 & $\begin{array}{l}\text { Philosophical or epistemological consequences explicitly mentioned as a learning outcome (e.g., discussion of interpretations, } \\
\text { thought experiments, Schrödinger's cat); }\end{array}$ \\
\hline Q11 & $\begin{array}{l}\text { One dimensional model (or particle in a box, potential well) mostly introduced with diagrams of the wave function to illustrate } \\
\text { quantized energy levels of a system; }\end{array}$ \\
\hline Q12 & Tunneling (the context might be alpha decay, explicitly presented as a result of tunneling); \\
\hline Q13 & $\begin{array}{l}\text { Atomic orbital model (also: electron cloud, } \\
\text { 3-dimensional potential well, different quantum numbers); }\end{array}$ \\
\hline Q14 & Pauli exclusion principle (used as the motivation of the shell model of the atom and as an explanation of the periodic table); \\
\hline Q15 & Entanglement (also called nonlocality, often with an explanation of the EPR experiment); \\
\hline Q16 & Schrödinger equation (only one-dimensional time independent); \\
\hline Q17 & $\begin{array}{l}\text { Calculation of detection probability, Born rule (probability = square of the magnitude of the wave function or square of phasor } \\
\text { length in the sum over path approach). }\end{array}$ \\
\hline
\end{tabular}


To structure the curriculum items (Table II) we adopted the literature themes we found during the selection of curriculum documents. Subsequently, we asked two faculty members that are involved in introductory QP lectures and two physics education researchers to assign the 17 curriculum topics according to the five content themes. Admitting that some curriculum items fit in more than one theme, we could agree on the grouping shown in Table III.

The curriculum topics listed as 'fundamental QP principles' represent concepts that show the disparity between classical physics and QP. For secondary school students, it is not possible to derive these principles from familiar characteristics of visible objects or any earlier learned school physics.

The items in the category 'phenomena and applications' are helpful to show students that QP is not only a theoretical construct but that it can explain real world phenomena and that there are useful applications of the theory. Many of these technical applications are essential for the life of secondary school students. In some countries, the 'atomic theory' items of Table III are covered by the chemistry curriculum (see Table VIII in Appendix B for more details). On that account, it does not imply that atomic theory is not taught in upper secondary school if we did not find it in the physics curriculum document of a country.

The mathematical side of QP is represented by the fourth theme in Table III. Unlike the "fundamental principles," all items in the category "wave function or other mathematical representation' involve calculations or at least graphical solutions of, e.g., the Schrödinger equation. All these topics can also be found in traditional university QP textbooks, although the mathematical complexity at university level is undoubtedly higher than in secondary education.

Arguably teaching all aspects of the category fundamental principles of QP can or even should involve philosophical considerations. From a practical point of view, experts agree that the iconic experimental results of the double slit experiment (Q5) and the EPR experiment (Q15) are very suitable to stimulate philosophical discourse in classrooms [13,46-49]. Moreover, with teaching about one of these two topics teachers inevitably have to address ontological and epistemological questions. In contrast to the previous theme, these questions are often neglected in calculus-based QP university courses [50,51]. For school physics, researchers argued that the philosophical aspects are especially valuable. For example, Myhrehagen and Bungum point out that it can help students to develop a qualitative understanding of QP if they compare their own interpretations with those of famous physicists [52]. Moreover, Pospiech argues that modern topics like teleportation and entanglement are fascinating topics for students because they need to modify their understanding of reality [53]. Including the philosophical side of QP in education implies many aspects
TABLE III. Thematic grouping of curriculum items.

\begin{tabular}{|c|c|c|}
\hline Theme & Code & Related curriculum items \\
\hline \multirow[t]{5}{*}{$\begin{array}{l}\text { Fundamental QP } \\
\text { principles }\end{array}$} & Q5 & $\begin{array}{l}\text { Wave-particle duality or } \\
\text { complementarity }\end{array}$ \\
\hline & Q8 & $\begin{array}{l}\text { Heisenberg's uncertainty } \\
\text { principle }\end{array}$ \\
\hline & Q9 & $\begin{array}{l}\text { Probabilistic or statistical } \\
\text { predictions }\end{array}$ \\
\hline & Q14 & Pauli exclusion principle \\
\hline & Q15 & Entanglement \\
\hline \multirow{6}{*}{$\begin{array}{l}\text { Phenomena and } \\
\text { applications }\end{array}$} & Q1 & Blackbody radiation \\
\hline & Q3 & $\begin{array}{l}\text { Discrete energy levels (line } \\
\text { spectra) }\end{array}$ \\
\hline & Q4 & $\begin{array}{l}\text { Interaction between light and } \\
\text { matter }\end{array}$ \\
\hline & Q6 & Matter waves, quantitative \\
\hline & Q7 & Technical applications \\
\hline & Q12 & Tunneling (e.g., alpha decay) \\
\hline \multirow[t]{5}{*}{ Atomic theory } & Q2 & Bohr atomic model \\
\hline & Q3 & $\begin{array}{l}\text { Discrete energy levels (line } \\
\text { spectra) }\end{array}$ \\
\hline & Q11 & $\begin{array}{l}\text { One dimensional model or } \\
\text { potential well }\end{array}$ \\
\hline & Q13 & Atomic orbital model \\
\hline & Q14 & Pauli exclusion principle \\
\hline \multirow{4}{*}{$\begin{array}{l}\text { Wave function or } \\
\text { other mathematical } \\
\text { representations }\end{array}$} & Q11 & $\begin{array}{l}\text { One dimensional model or } \\
\text { potential well }\end{array}$ \\
\hline & Q12 & Tunneling \\
\hline & Q16 & Schrödinger equation \\
\hline & Q17 & $\begin{array}{l}\text { Detection probability as square } \\
\text { of the magnitude } \\
\text { of the wave function or square } \\
\text { of the phasor } \\
\text { length in the sum over path } \\
\text { approach }\end{array}$ \\
\hline \multirow[t]{3}{*}{$\begin{array}{l}\text { Philosophical aspects } \\
\text { of QP }\end{array}$} & Q5 & $\begin{array}{l}\text { Wave-particle duality or } \\
\text { complementarity }\end{array}$ \\
\hline & Q10 & $\begin{array}{l}\text { Philosophical or epistemological } \\
\text { consequences } \\
\text { explicitly mentioned as a } \\
\text { learning outcome } \\
\text { (e.g., discussion of } \\
\text { interpretations, thought } \\
\text { experiments, Schrödinger's } \\
\text { cat) }\end{array}$ \\
\hline & Q15 & Entanglement \\
\hline
\end{tabular}

of NOS as described in the theoretical framework of this article.

\section{Method of QP curriculum items analysis}

To identify similarities and differences between the content of quantum physics in secondary school physics 
in different countries (our second research goal), we analyzed the results in two steps: First, we derived the international current core curriculum for QP. Subsequently, we analyzed all curriculum items to explore possible thematic foci.

\section{Determining the core curriculum}

We identified the most prevailing curriculum items from our overview of 15 countries. To find these favored curriculum items, we compared the frequencies of the items across the collected documents. To avoid overrepresentation of countries with more than one curriculum document in our survey, we counted the countries-not the number of documents-in which each content item occurs. The set of items that are most common in teaching QP on the secondary level can be called the current core curriculum for QP.

\section{Thematic analysis of curriculum focus}

To determine the central themes of QP in secondary education, we compared the items of the current core curriculum with the five themes (i) fundamental QP principles, (ii) phenomena and applications, (iii) atomic theory, (iv) wave function or other mathematical representations and (v) philosophical aspects of QP. We further analyzed the curriculum documents of educational systems which introduce students to more aspects of QP than only the core curriculum. We sought to find the focus of these curricula by exploring if the extra content items concentrated around a specific theme.

\section{NOS in physics curriculum documents}

The goal of this part of the research is twofold. First, we investigate if the NOS aspects that we assume essential for developing QP concepts are in principle addressed in the curriculum documents. And second, we explore if and how QP and NOS are linked in curriculum documents.

We first scrutinized each of the 23 entire curriculum documents for upper secondary school physics to identify passages that address one of the earlier identified NOS aspects: Methodology (e.g., working with hypothesis and experiments) (N1), the role of scientific models (N2), tentativeness of science (N3), creativity in science (N4), controversies in science (N5), and history of science (N6). For each curriculum document, we registered which of the NOS items was visible in the text.

As summarized in Table I, there are evident relations between QP and multiple aspects of NOS. After the identification of general NOS statements in the curriculum documents, we analyzed if NOS aspects are addressed in the context of QP; we searched for descriptions of learning outcomes that combine NOS with QP. In this part of our study, we do not aim to make any quantitative statements but to find examples of documents in which certain QP content items are explicitly linked with NOS in different curriculum documents.

\section{RESULTS}

\section{A. Curriculum documents}

Our search for curriculum documents, containing references to the teaching of QP in secondary school, gave a variety of macrolevel sources differing in form and level of detail. Some are written as coherent reflective texts; other documents consist mainly of itemized tables. These documents are published under different names (after translation): national curriculum, national learning plan, learning standards, content standards, syllabus, examination program, or exam specifications. In some countries, several equivalent syllabi exist in parallel. To give an uncluttered international overview of the various curriculum contents, we selected only a few sample documents from these countries. In the country-specific information in Appendixes A and B, we elucidated these selections. For the analysis in our research, we finally used 23 different curriculum documents originating from 15 different countries: Australia, Austria, Belgium, Canada, Denmark, Finland, France, Germany (documents of 7 states), Italy, Netherlands, Norway, Portugal, Spain, Sweden, and the United Kingdom (2 documents). The original sources of the curriculum documents are listed in Table VII in Appendix A. In most of these countries QP items are taught in an elective physics course in the final high school years, typically for students aged 17 to 19 . Only in the curriculum document of the German federal state of Bavaria, we found QP items, like wave-particle duality, in the general physics course for all 15- to 16-year-old students. In some countries, teachers have the option to choose between several advanced physics options (e.g., relativity or astronomy or quantum physics).

\section{B. QP curriculum items}

Although most analyzed physics curricula are divided into thematic sections, QP is not a separate section in every country. Often the QP items are combined with items from nuclear physics or relativity in a section called "Modern Physics" or similar. In some countries, the QP items are spread over different sections such as "atomic models," "radiation," or "revolutionary ideas." The curriculum content is often presented in a tablelike structure, sometimes with extra information about contexts, explanations, lesson time, and competence aims with the expected depth of knowledge, formulas, or example questions. What kind of extra information is given in the document partly depends on the role the curriculum is expected to fulfill, as mentioned above. In countries with oral exams, teacherset exams or QP as an optional subject (e.g., Belgium or Austria), the curricula are more general and mention various optional items, whereas countries with QP in an 
externally set high stakes standardized school-leaving exam (e.g., the UK, the Netherlands, and most German states) give more detailed specifications.

To illustrate the various styles of curriculum documents we show some-if necessary, translated-sections regarding the items Q5 and Q6 in Table IV: We gave the item code Q5 ("wave-particle duality") to all statements concerning the central idea that in QP light and particles cannot be described as in classical physics. Several curriculum documents mention key experiments like the double-slit experiment or the Mach-Zehnder interferometer, in which this quantum property can be explained conceptually. Other documents do not mention such details but cover the same concept in general terms. Item code Q5 thus stands for a qualitative understanding; calculations and formulas are not necessary. Item Q6 ("Matter waves, quantitative") concerns the mathematical use of the same aspect, mainly for calculations with the de Broglie wavelength.

Our examples in Table IV demonstrate that the styles of official curriculum documents are noticeably different, which is related to the divergent functions these documents fulfill in the educational systems. Educators and textbook developers in all countries use these official texts, but the rigor of definitions in the curriculum documents differ from country to country. The quotes in Table IV show that Finnish and Austrian curriculum documents use open terms to describe the required course content. This unspecific description gives teachers vast possibilities to interpret the curriculum document and define learning outcomes themselves. On the contrary, the intended student competencies are described in high detail in the curriculum document like that of the German federal state of Baden Württemberg. Although teachers have the freedom to design their own lessons, such a syllabus will ensure that the physics lessons will cover all listed competencies to prepare students for their high stakes exams. Despite the differences in styles, it is our goal to give a clear overview of curriculum items. Therefore, we grouped countries with similar examination systems next to each other in Table V because a similar way of examination makes the curriculum documents more comparable, as explained in Sec. I. The symbols we used in Table V are explained in the legend, but for clarity about the use of "compulsory" or "optional," some extra information: A filled square ( $\mathbf{\square}$ ) indicates a compulsory item of an upper secondary school physics course (students ages 17-19). In most cases, this is an elective course. If the curriculum document explicitly mentions an item as optional for the teacher (e.g., some curricula allow teachers to choose between different advanced physics topics) we use an open square ( $\square$ ).

\section{Results of the curriculum items analysis}

As indicated in the methods section we conducted two types of analysis: a compilation of the most frequently included curriculum items and an analysis of differences between curriculum documents. After collecting the data in Table V, we found it problematic to include "black body radiation" (Q1) and the "Bohr model of the atom" (Q2) in our study. Historically both items were steps in the development of QP, but they are not necessary to understand or support any other QP concept. Furthermore, in some countries, blackbody radiation is mentioned in the context of astrophysics, not QP. Moreover, the Bohr model of an atom belongs to chemistry in several countries. In some educational systems, physics and chemistry are taught as a combined subject, and Bohr's atomic model is solely used to explain atomic spectra and chemical bonding without relation to QP. Consequently, the presence of Q1 and Q2 in the list is ambiguous. For completeness, we include these items in the frequency table, but we decided to not include them in our further analysis.

\section{Current core quantum curriculum}

In Table VI we show the frequency of different items across countries and across all documents in this study. As explained in Sec. III our units of analysis are countries for this part of the research.

"Discrete energy levels" (Q3), "Interaction between light and matter" (Q4), "Wave-particle duality" (Q5), "Matter waves, quantitative" (Q6) and "Technical applications" (Q7) are undoubtedly the most commonly occurring QP items. At least 12 of the 15 different countries and the IB program (see Table V) mention these learning outcomes. The next two items "Heisenberg's uncertainty principle" (Q8) and the "Probabilistic nature of QP" (Q9) are included in at least 8 of the 15 national curriculum documents. Although the probabilistic nature of $\mathrm{QP}$ is not explicitly mentioned in all curriculum documents, this concept is probably included in textbooks and lessons in most countries. It is inevitable to address the statistical character of predictions for a correct description of the double slit experiment with single quantum objects. The items that are mentioned in the majority of the countries (Q3 to Q9) define the international current QP core curriculum on the secondary level. The QP curriculum content of the following countries is a subset of this core curriculum: Australia, Canada (province Ontario), Denmark, England, Finland, France, German (state Baden Württemberg), Portugal, and Spain. The name "core curriculum" is even more appropriate, if we take into account educational systems with two different advanced physics courses-either consecutive courses or alternative courses: Table V shows that nearly all basic courses solely mention content items confined to the core curriculum.

The curriculum items Q10 to Q17 only occur in a few documents. The topics are diverse and can be seen as extensions of the core curriculum (Fig. 1). Items that exist in the curriculum documents of at least three countries are "Philosophical consequences" (Q10), the "One-dimensional model or potential well" (Q11), and 
TABLE IV. Example Q5 and Q6 in different curriculum documents.

\begin{tabular}{|c|c|c|}
\hline Country (chapter in the curriculum) & $\begin{array}{c}\text { Citation of a part of the curriculum document: In italics } \\
\text { the statements regarding Q5 and Q6 }\end{array}$ & Item code \\
\hline $\begin{array}{l}\text { Finland (specialization course F8: } \\
\text { "Matter and Radiation") }\end{array}$ & The particle nature of radiation and the wave nature of particles; & Q5 \\
\hline $\begin{array}{l}\text { Austria (Competence module } \\
\text { "quantum physics") }\end{array}$ & $\begin{array}{l}\text { Special characteristics of the quantum world, the double-slit experiment, } \\
\text { Heisenberg's uncertainty principle, statistical interpretation. Insight into } \\
\text { theory development and the world view of modern physics. }\end{array}$ & Q5 \\
\hline Norway (Physics 2: Modern physics) & $\begin{array}{l}\text { The studies aim to enable pupils to give an account of Einstein's explanation } \\
\text { of photoelectric effect and give a qualitative account of how results from } \\
\text { experiments with photoelectric effect, Compton scattering and the wave } \\
\text { nature of particles represents a break with classical physics }\end{array}$ & Q5 \\
\hline $\begin{array}{l}\text { Canada, Ontario (Revolutions in } \\
\text { Modern Physics: Quantum } \\
\text { Mechanics and Special Relativity) }\end{array}$ & $\begin{array}{l}\text { Light can show particlelike and wavelike behavior, and particles can show } \\
\text { wavelike behavior. By the end of this course, students will describe the } \\
\text { experimental evidence that supports a wave model of matter (e.g., electron } \\
\text { diffraction). }\end{array}$ & Q5 \\
\hline \multirow{4}{*}{$\begin{array}{l}\text { England, Wales and Northern Ireland } \\
\text { (AQA A-level specifications, The } \\
\text { discovery of photo electricity) }\end{array}$} & de Broglie's hypothesis: $p=\frac{h}{\lambda}$ & Q6 \\
\hline & $\lambda=\frac{h}{\sqrt{2 \mathrm{meV}}}$ & Q6 \\
\hline & $\begin{array}{l}\text { Low-energy electron diffraction experiments; qualitative explanation of the } \\
\text { effect of a change of electron speed on the diffraction pattern. }\end{array}$ & Q5 \\
\hline & $\begin{array}{l}\text { Electron microscopes: Estimate of anode voltage needed to produce } \\
\text { wavelengths of the order of the size of the atom. }\end{array}$ & Q6 \\
\hline \multirow[t]{7}{*}{$\begin{array}{l}\text { Germany, Baden Württemberg } \\
\text { (Two-hour course with emphasis } \\
\text { on quantum physics) }\end{array}$} & $\begin{array}{l}\text { The students recognize that any classical model fails to describe the behavior } \\
\text { of quantum objects entirely and consistently. In particular, they recognize } \\
\text { that quantum physical experiences and experiments call into question } \\
\text { familiar concepts and question concepts like determinism, causality or } \\
\text { trajectory. They describe that behavior of quantum objects using } \\
\text { probability statements. }\end{array}$ & Q5 \\
\hline & $\begin{array}{l}\text { The students can: Describe similarities and differences in the behavior of } \\
\text { classical waves, classical particles and quantum objects at the double-slit } \\
\text { experiment. }\end{array}$ & Q5 \\
\hline & $\begin{array}{l}\text { Explain that for quantum objects probability statements replace the } \\
\text { determinism of classical physics. }\end{array}$ & \\
\hline & $\begin{array}{l}\text { Describe interference experiments with single quantum objects using } \\
\text { probability statements, and explain the outcome of the experiments. }\end{array}$ & Q5 \\
\hline & $\begin{array}{l}\text { Describe that quantum objects always have wave and particle properties, but } \\
\text { that these properties cannot be observed independently of each other. } \\
\text { Students use quantum interference properties and which-way information } \\
\text { for individual quantum objects (for example double-slit experiment or } \\
\text { Mach-Zehnder interferometer) }\end{array}$ & Q5 \\
\hline & $(\ldots)$ & \\
\hline & $\begin{array}{l}\text { Explain how quantum objects can be described by their energy and their } \\
\text { momentum, } E_{\text {quant }}=h \cdot f, p=\frac{h}{\lambda} \text {, de Broglie wavelength of matter waves }\end{array}$ & Q6 \\
\hline
\end{tabular}

"Tunneling" (Q12). These items are not necessarily related to each other and occur independently in some curriculum documents.

\section{Thematic foci of curricula}

We found that the content focus of the secondary school QP curricula lies primarily in the fundamental principles and the phenomena and applications. All of the seven content items from the core curriculum belong to these two categories. Consequently, high school students from most countries will mainly get to know fundamental principles and phenomena and applications of QP in an advanced physics course. It is interesting to note that the three items from the Bavarian general physics course for 15- to 16-year-old students all belong to the category fundamental principles; phenomena and applications are not explicitly mentioned.

The extra content from advanced physics courses stems from the other three categories. Figure 2 shows how the extra items of different curriculum documents can be categorized: The IB diploma program and the Scottish 


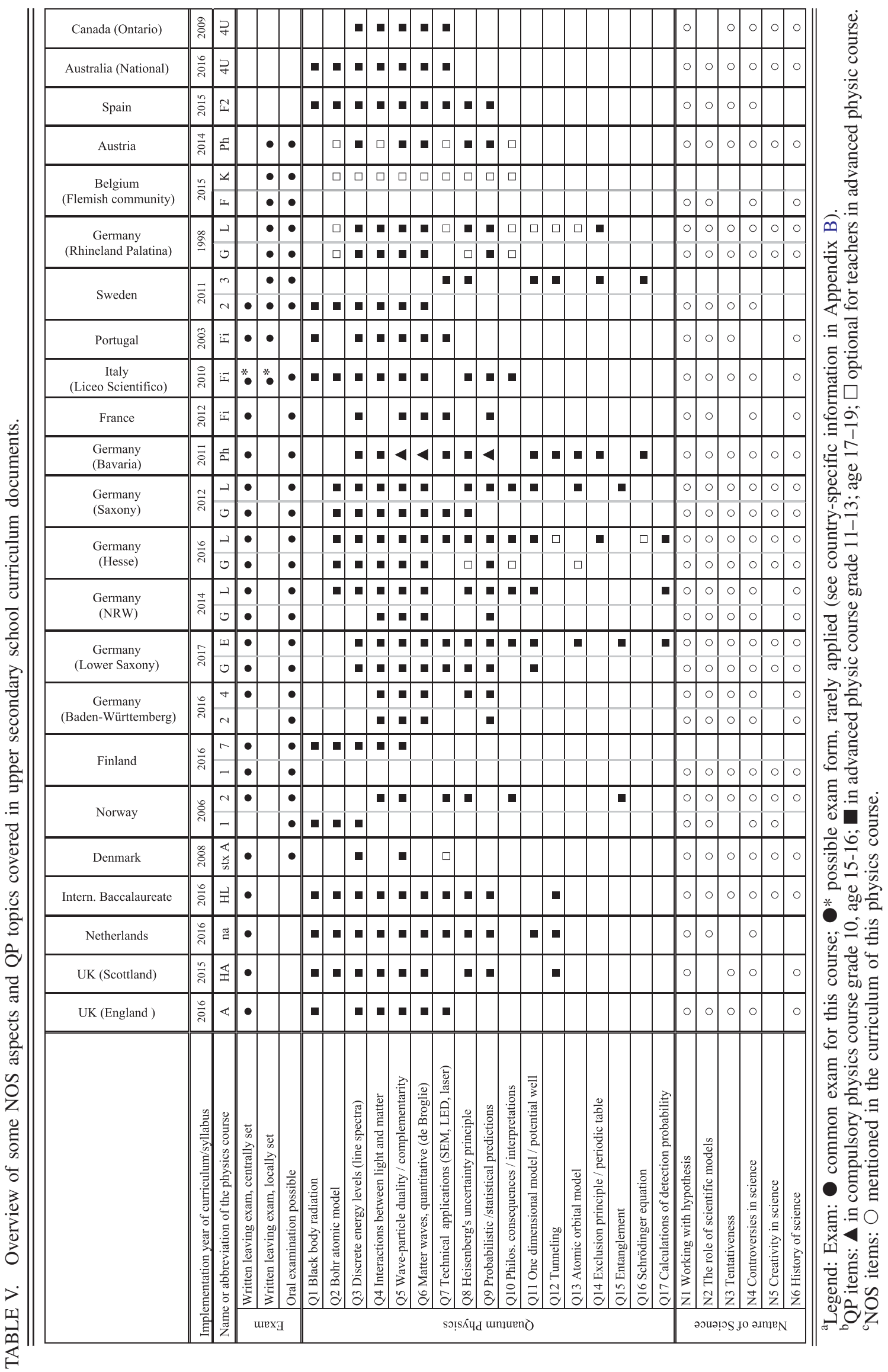


TABLE VI. Frequency of QP curriculum items for different countries and all scrutinized documents.

\begin{tabular}{llcc}
\hline \hline Content item mentioned in the curriculum document & Countries/15 & Documents/23 \\
\hline Q1 & Blackbody radiation & $(9)$ & $(11)$ \\
Q2 & Bohr atomic model & $(13)$ & $(15)$ \\
Q3 & Discrete energy levels (line spectra) & 15 & 22 \\
Q4 & Interactions between light and matter & 13 & 21 \\
Q5 & Wave-particle duality or complementarity & 15 & 23 \\
Q6 & Matter waves, quantitative (de Broglie) & 12 & 20 \\
Q7 & Technical applications & 13 & 18 \\
Q8 & Heisenberg's uncertainty principle & 9 & 16 \\
Q9 & Probabilistic or statistical predictions & 8 & 15 \\
Q10 & Philosophical consequences or interpretations & 5 & 9 \\
Q11 & One-dimensional model or potential well & 3 & 8 \\
Q12 & Tunneling & 4 & 7 \\
Q13 & Atomic orbital model & 1 & 5 \\
Q14 & Exclusion principle or periodic table & 2 & 4 \\
Q15 & Entanglement & 2 & 3 \\
Q16 & Schrödinger equation & 2 & 3 \\
Q17 & Calculations of detection probability & 1 & 3 \\
\hline \hline
\end{tabular}

advanced higher physics course focus on the wave function and other mathematical representations; the Netherlands and Sweden have additional items from the atomic theory in their extra content; most German states have extra items from all three categories. In contrast, the extra items of Norway and Italy focus solely on philosophical aspects. Also the Belgian and the Austrian curriculum documents contain philosophical consequences, but in both countries, they are only mentioned as an optional suggestion. There was no QP curriculum document that mentioned atomic theory without any item from the category "wave function or other mathematical representation."

We take the two Scandinavian countries Sweden and Norway to illustrate how the core curriculum of the two countries is similar, but the extensions have a very different focus. Both countries have two successive advanced physics courses; for clarity, we call them "basic advanced" and "higher advanced" for both countries. Figure 3 shows the themes of these courses according to our thematic content analysis

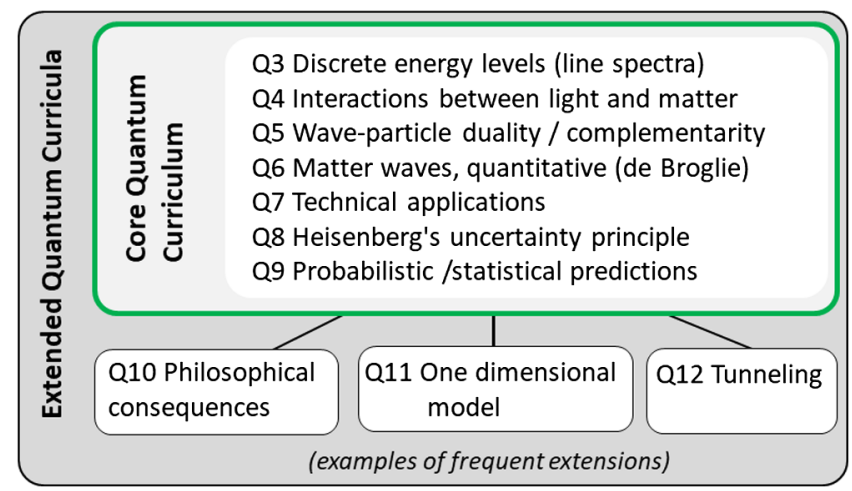

FIG. 1. International core curriculum and extensions.

\section{NOS in curriculum documents \\ 1. NOS in every curriculum document}

In the majority of the curriculum documents, the NOS aspects are formulated as desiderata and not as a list of mandatory test items or detailed descriptions like the QP topics. Examples of these generic formulations from Denmark and Italy can be found in Appendix C. In some countries, though, NOS aspects are explicitly formulated as learning outcomes. For example, in most German curriculum documents, all content items are linked to specific investigation skills or competencies that the students should master at a particular stage of their school career. These competencies also contain analytical, epistemological,

\section{Focus of the extra items:}

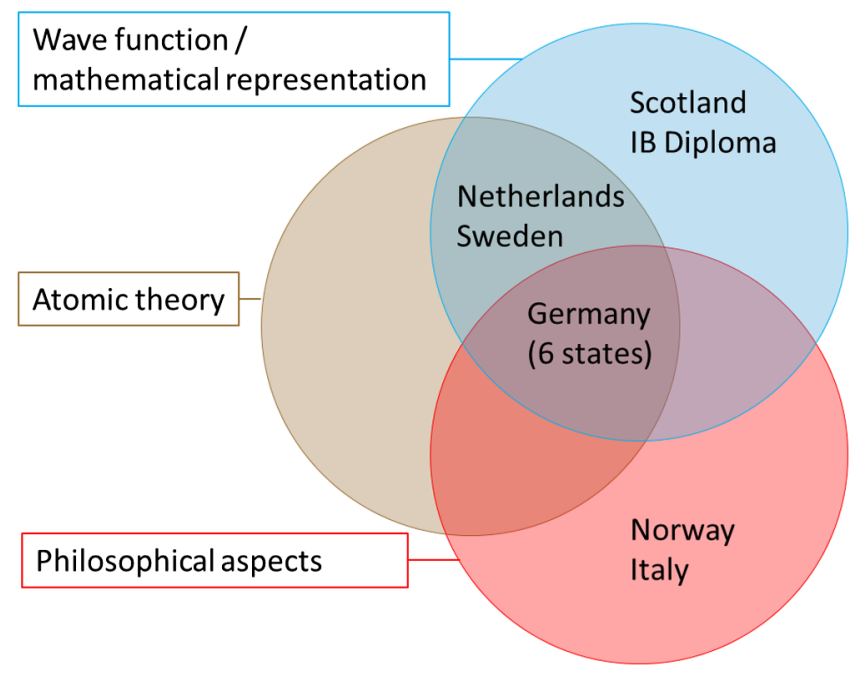

FIG. 2. Different national curriculum documents grouped according to the thematic focus of extensional QP items. 


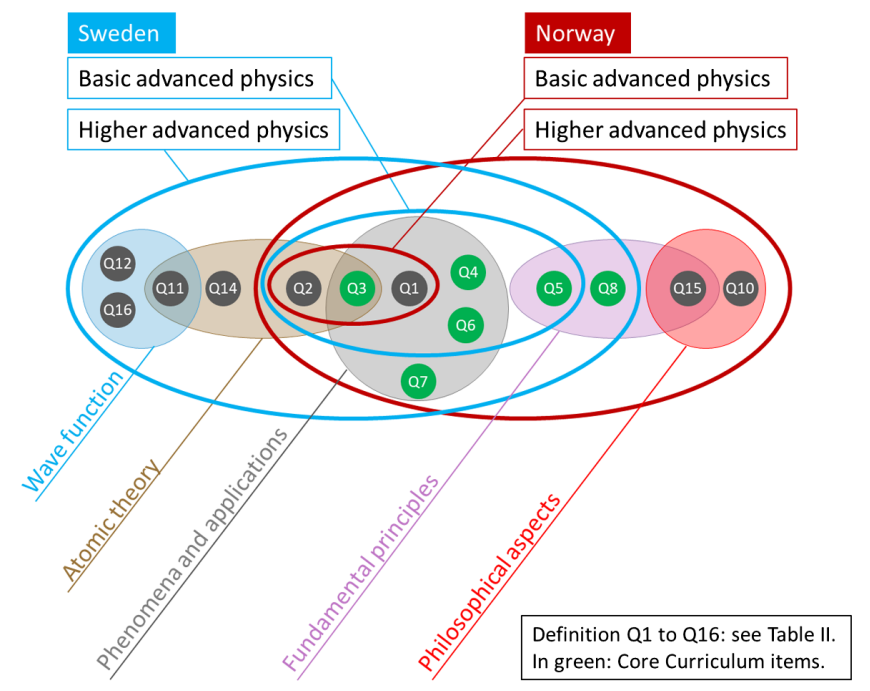

FIG. 3. Thematic foci of two Scandinavian curriculum documents: The Swedish curriculum is strong in mathematical descriptions and atomic theory whereas the Norwegian focus lies on philosophical aspects.

argumentation, and judgment aspects that are related to NOS and scientific literacy. Also, in the curricula of Australia and Ontario (Canada), NOS aspects play an important role. Achievement levels of the intended learning outcomes for several NOS aspects are accurately described in the investigated documents from these countries (see examples of Australia in Appendix C).

Remarkably, in the physics guide of the IB diploma programme, six pages are devoted to a discussion of NOS and scientific literacy. In the syllabus, each content topic is linked to NOS by an "essential idea." The connection between content topics and NOS is clearly explained, and for each topic, NOS aspects are also integrated into the internal assessments of the IB program but not in the written external exams.

While the way in which NOS is presented in curriculum documents is very diverse, all countries mention most or even all aspects from the six categories we identified as relevant for QP (see Table I and Table V). "Methodology (e.g., working with hypothesis and experiments)" (N1) is explicitly mentioned in all curriculum documents. "The role of scientific models" (N2), "Tentativeness of (N3), "Controversies in science" (N4) and "History of science" (N6) can be found in at least 20 of the 23 curriculum documents (or at least in 12 of the 15 countries). Only the NOS aspect "Creativity in science" (N5) is not very common. We found it in 12 of the 23 curriculum documents and only in six of the 15 different countries.

\section{Scarce explicit $Q P-N O S$ connections}

Only a few curriculum documents make the connections between QP items and specific NOS aspects explicit in their learning outcomes. Generally, these are the elaborate documents with well-defined multidimensional achievement levels. In the examined documents, we basically found three variants of coupling between QP items and NOS aspects: (1) Explicit connection of content-related specifications of defined competencies, (2) integration of NOS in the structure of the curriculum document, and (3) single NOS aspects mentioned as an integrated part of a content item. In the following, we will show examples for each of these explicit connections.

(1) Intended achievement levels from the curriculum document of North Rhine-Westphalia, Germany:

"The students show examples of the limits (...) of wave and particle models for light and electrons (B4, K4), [and] describe and discuss the controversy surrounding the Copenhagen interpretation and the wave-particle dualism (B4, K4)” (p. 31).

In this document, the abbreviations B4 and $\mathrm{K} 4$ refer to earlier defined evaluation and communication skills that are related to the NOS aspects N2 (the role of scientific models) and N4 (controversies in science) from this research.

(2) As mentioned above, in the IB physics guide NOS is central. Each paragraph of the curriculum document starts with the NOS aspect that is visible in the content of this paragraph. For the paragraph "The interaction of matter with radiation" this is "Observations: Much of the work towards a quantum theory of atoms was guided by the need to explain the observed patterns in atomic spectra. The first quantum model of matter is the Bohr model for hydrogen. Paradigm shift: The acceptance of the wave-particle duality paradox for light and particles required scientists in many fields to view research from new perspectives." (p. 90). In our categorization of NOS items, these statements belong to N1 [methodology (e.g., working with hypothesis and experiments)] and N6 (history of science).

(3) The paradigm shift—as an aspect of the history of science-is in several curriculum documents the only explicit connection between NOS and the QP content. For example, the Scottish document says, "Quantum theory can be introduced by consideration of experimental observations that could not be explained by classical physics, together with the various efforts made to resolve these dilemmas." (p. 23) In the Norwegian curriculum, it is formulated as, "The aims of the studies are to enable pupils to $[\ldots]$ give an account $[\ldots]$ of how the wave nature of particles represents a break with classical physics." (p. 6)

In summary, we can say that explicit connections between QP content items and NOS are only given for certain NOS aspects in some countries. The most extensive connections between NOS and QP can be found in 
documents that do not treat NOS in a separate chapter, but structurally integrate cognitive skills and epistemological aspects in the physics curriculum.

\section{DISCUSSION}

\section{A. Core curriculum and NOS}

In this article, we gave a structured overview of QP topics in upper secondary school curricula of 15 different countries. Identifying the seven most prevalent QP content items in these countries led to our definition of a current QP core curriculum (see Fig. 1). What does this core curriculum tell us about QP in secondary schools?

First, from the fact that we were able to find QP topics in 15 countries, we conclude that it is not only accepted to teach aspects of QP on the upper secondary level in some experimental setup, but that it has now become the standard educational practice in many countries. In most investigated countries QP is part of an elective advanced physics course for 17- to 19-year-old students typically taken by $5 \%$ to $20 \%$ of the overall student population [20]. In preuniversity schools of Germany or the Netherlands, $40 \%$ to $50 \%$ of the upper secondary students take advanced physics in their final exams [54,55]. Notably, we found one curriculum document in which some central aspects of QP are even taught to a broader and younger group of students. In the German state of Bavaria wave-particle duality and the probabilistic nature of QP is in the compulsory science curriculum for all 14- to 16-year-old pre-university students (in $201731 \%$ of the cohort [56]). While it is not common and might seem ambitious that students learn some central ideas of modern physics at middle school age, there are some indications that this is possible. For instance, a comparable teaching project with 14- to 16-year-old students in Australia shows that core concepts of "Einsteinian physics" are intelligible for students of this age group and that the program significantly increased girls' interest in physics [57,58]. Second, in contrast to the difficulty to define a core content of introductory quantum mechanics courses on the undergraduate level [59], our research shows that on the secondary level there is a high correspondence of core QP content items in different countries. Certainly, it is important to bear in mind that for secondary education the intended learning outcomes of each authority is more than a list of content items. Most curriculum documents contain overarching goals and describe the desired development of students' understandings, competencies, and skills like the level of problem-solving abilities. These pedagogically elaborated goals are not a subject of this study. However, by perusing the items of the current core curriculum, we got an impression of what topics are regarded as achievable basics of QP for upper secondary schools in many countries. We will discuss the content items of the international current core curriculum in detail.

\section{1. (Quasi-)history}

Remarkably, the two most common items "Discrete energy levels (line spectra)" (Q3) and "Interaction between light and matter, for example, the photoelectric effect" (Q4) do not necessarily require QP. For example, spectral lines can be-and frequently are-explained with a planetary Bohr model of the atom [60]. Likewise, several authors point out that the presentation of the photoelectric effect in many textbooks is oversimplified and might not enhance students' understanding of QP [61-64]. However, the popularity of these items supports the findings of Kragh, who already in 1992 found that "Virtually all textbooks introduce the quantum postulate- that is, the necessity of conceiving physical processes as discontinuous at the atomic or subatomic level-by referring to a number of experimental facts that were discovered in the early part of the twentieth century and which seem inexplicable without the hypothesis of quantization." [27] (p. 351). He found that most textbooks oversimplify the actual course of history by presenting the photoelectric effect as an unsolved problem that was brilliantly explained by Einstein and consequently led to the introduction and acceptance of the new quantum theory. Science education researchers identified this praxis as a quasihistorical approach in which historical experiments and discoveries are presented as if the chronological order of evidence of failures of classical physics made the development of a new theory necessary [27,65]. Historically, the development of ideas in science is much more complicated. In particular, the early years of QP were characterized by controversies, presuppositions, contradictions, and inconsistencies [14]. Leaving away all these struggles seems to be a justified simplification in textbooks, but on the other hand, it is a deprivation of giving students more insight into NOS [18,61].

A reasonable explanation for the popularity of line spectra and the photoelectric effect is that both phenomena can be demonstrated in relatively simple experiments within the means available in most high schools. Especially for a theoretical topic like QP, experiments are regarded as important for students' understanding [66]. Moreover, for example, interactive computer simulations in which students can manipulate the setup of the photoelectric effect can be useful to stimulate inquiry-based learning [67,68]. Nevertheless, curriculum developers should be aware of the disadvantages of a quasihistorical introduction to QP. They might consider a genuinely historical approach which offers many chances for NOS teaching or a different introduction of QP, for example via two-level systems (see below).

\section{Tradition and uncertain interpretation}

The items "Wave-particle duality, also called complementarity" (Q5), "Matter waves, quantitative (calculations with De Broglie wavelength)" (Q6), "Heisenberg's uncertainty principle" (Q8), and "Probabilistic or statistical 
predictions" (Q9) are all indispensable in the academic tradition of QP teaching [47] and they also emerged in the list of key topics in a recent Delphi study amongst Dutch academic experts about teaching QP in secondary education [69]. On the one hand, the reason for this seems obvious: Stating that light and particles have both particle and wave nature is evidently different from classical physics and a fundamental key concept in QP. Moreover, emphasizing the differences between a classical worldview and a QP view is advocated to be crucial in developing students' understanding of quantum concepts $[53,70,71]$. On the other hand, it is remarkable that waveparticle duality also can be found in syllabi of countries with high stakes exams that do not mention any philosophical aspects. One may wonder what kind of examination problems can be developed on wave-particle duality because answers depend on the interpretations of QP, and consensus on a "correct interpretation" [72,73]. McKagan et al. [59] have pointed at the problem of developing good concept test questions on duality, because of different QP interpretations. Although wave-particle duality can be found in virtually every QP curriculum, and it is seen as a central concept in teaching QP [40,53,59,69,70,74], students and teachers might not be aware of different possible interpretations. Most curriculum documents do not give detailed information on how wave-particle duality should be understood. We often found formulations such as "By the end of this unit, students (...) evaluate the experimental evidence that supports (...) wave-particle duality" (Australia, p. 42) or "The candidate can (...) apply the wave-particle duality for explaining interference phenomena in electromagnetic radiation and in matter particles" (Netherlands, p. 26), which are open to various QP interpretations, but do not address the existence of any interpretations at all.

Teachers, textbook authors, or test developers who work on the basis of these curriculum documents have to decide if they avoid interpretations of QP, if they use a specific interpretation, or if they want to address several interpretations. Research in American university courses shows that if instructors do not mention any interpretation of the wave-particle duality, that students are more likely to use realist interpretations which is commonly not the desired understanding of QP [50]. However, leaving the choice for a specific interpretation to the educators is also problematic because different interpretations of wave-particle duality require different analogies, different educational strategies like simulation, and different test questions [40]. For the development of unambiguous test marking schemes, it seems a prerequisite to state which interpretation of QP has to be taught. Therefore, more clarity for the use of QP interpretations in most curriculum documents would be desirable.

That it is actually possible to offer more support in how to address wave-particle duality is shown by the French, some German, and the Norwegian documents. The French national curriculum document mentions one specific interpretation, namely, that the photon is neither a wave nor a particle. In additional curriculum texts and some French textbooks, such quantum objects are called "quantons" to underline the novelty of QP [75]. However, in 2015 Lautesse et al. found that most French secondary school physics textbooks still use classical terminology like wave and particle to describe light or electrons which contradicts the intended clarity of the official curriculum document [76].

Some other curriculum documents explicitly address interpretations of QP. For example, the German document of North Rhine-Westphalia (NRW) says "The students describe and discuss the controversy surrounding the Copenhagen interpretation and the wave-particle dualism." (p. 31) and "The students explain that the wave-particle dualism is abolished by the probability interpretation" (p. 45). The Norwegian curriculum document emphasizes the qualitative description of quantum phenomena and requires students to be able to discuss philosophical and epistemological aspects of NOS [77]. For educational research, it would be interesting to examine how teaching different interpretations affects students' understanding of QP and NOS.

\section{Technical applications}

A unique item of the current QP core curriculum is "Technical applications (e.g., scanning electron microscope SEM, light emitting diode LED, semiconductors, and laser)" (Q7). This curriculum item reflects the effort to show students real-world applications of physics theory, which is often advocated as making physics lessons more attractive to students [10,78]. Without the evidence of real quantum technology, students might regard QP as some weird theoretical-philosophical or mathematicalconstruct. Frequently working with different examples also enables students to transfer theoretical concepts to various new contexts [79-81]. In contrast to the other core curriculum items, technical applications commonly do not belong to the academic tradition of introductory QP teaching [82]. Certainly, there are diverse university courses that cover applications of QP in various scientific fields, but for the early introduction of QP, this curriculum item is unique.

\section{B. Thematic foci and NOS}

In our analysis of the less common curriculum content outside of the core curriculum, we were able to identify three thematic foci: wave function or other mathematical representation, atomic theory, and philosophical aspects. Countries that introduce secondary students into more than the QP core curriculum expand the curriculum into one or a combination of these three themes (see Fig. 2). In comparing the national curricula of Norway and Sweden, we 
showed how these two countries share a similar content in their basic course but introduce students to very different aspects of QP in the higher advanced physics courses (see Fig. 3). Why would a choice for a specific focus be made in a curriculum?

Each focus offers possibilities to present a different facet of the nature of physics, and what is taught might illustrate a specific understanding of why we teach physics. A focus on atomic QP connects the content of chemistry and physics. Including the wave function, or other mathematical descriptions resembles the traditional introduction of QP at university level and could serve as an orientation on this, whereas a philosophical focus facilitates discussing the NOS [77]. Different foci thus reflect what Osborn and Dillon call the dual mandate of science education: serving "the needs of future scientists and the need of the future non-scientists." In their critical reflections on European science education, they state that traditionally "the content of the science curriculum has largely been framed by scientists who see school science as a preparation for entry into university rather than as an education for all" [83]. Clearly, the mathematical representation of QP in curriculum documents (see the Swedish example in Fig. 3) is a result of this traditional understanding of the purpose of science education. It also explains why experts from Dutch universities chose the mathematically demanding wave function as a relevant content item for secondary school physics in a recent Delphi study [69]. If, in contrast, an upper secondary QP course also aims to develop students' ideas about science, a philosophically oriented curriculum focus offers more possibilities. The Norwegian example shows how students can get acquainted with NOS aspects like controversies about the interpretation of QP and actively participate in argumentations about philosophical aspects of QP [84-86]. While such integration of NOS in school physics is favored in contemporary science education literature, it seems difficult to assess it in standardized exams because there typically is no "right" or "wrong" answer. This is presumably why we found philosophical aspects of QP mainly in the curriculum documents of countries with oral exams or locally set final exams (see Table V).

\section{CONCLUSION, CHALLENGES, AND FUTURE POSSIBILITIES}

We can conclude that-in contrast to the research results from 2005 [19]—QP is taught in upper secondary schools in many countries now, and there is a common core curriculum. However, in light of physics education research, we see more possibilities to connect NOS teaching with QP, and the current core curriculum might not necessarily be the best way of introducing QP on a conceptual level. As mentioned earlier, our analysis of curriculum documents cannot always give an authentic image of what happens in classrooms. Textbooks and teachers make their own choices in the framework of the curriculum and exam requirements. It would be valuable to study textbooks and classroom practices in different countries in the future. At the moment, it seems that the most common approach is quasihistorical with elements from traditional university quantum mechanics courses. Certainly, it is unrealistic to expect surprising curriculum innovations in most countries, because developing and changing national standards is generally a complex and slow process which often involves different stakeholders [87]. However, we discovered interesting details in the curriculum of some countries which makes secondary QP more than a copy of the "what we have always done in higher education" without the mathematical depth. Some of these "unusual" items might be seeds that grow bigger and might appear in a larger number of national curriculum documents over time. Items we want to mention in this category are not only the philosophical consequences of QP but also quantum entanglement and its application. At the moment the latter is only mentioned in the Norwegian and two German curriculum documents.

Quantum entanglement has far-reaching philosophical consequences which not only evoke NOS teaching but also have the potential to motivate students [49]. Many authors argue that understanding QP concepts could become much easier for students if we would introduce the concepts with entanglement experiments of two-level systems [88-92]. This approach, which is also called the qubits approach, spin-first approach or Dirac approach [92-94] emphasizes the fundamental role of the superposition principle in QP. Several activating pedagogical strategies-for example, simulated experiments for students to work with-have recently been developed [95-97]. The proponents of this pedagogical approach expect that students grasp the key concepts and philosophical consequences of QP directly and much easier with two-level systems because they do not have to go through all the same problems as physicists in the first phase of the development of the quantum theory. Further research has to be done to investigate the educational possibilities that could be pursued on a larger scale.

\section{ACKNOWLEDGMENTS}

We want to thank the following experts from different countries who helped us to understand national school systems and curriculum documents. Helen Gourlay (UK); Graeme Anderson (IB); Berit Bungum (Norway); Tommi Kokkonen (Finland); Rainer Müller, Torsten Franz, Josef Küblbeck, Helmut Fischler (Germany); Clément Crastes (France); Marco Alessandro Luigi Giliberti (Italy); Paulo Simeão Carvalho (Portugal); Rita Van Peteghem, Wim Peeters, Mieke De Cock (Belgium); Martin Hopf (Austria); Ángel Vázquez-Alonso (Spain); and Elaine Horne (Australia). The research for this article is supported by DUDOC $(\mathrm{PhD}$ grant for teaching and teacher related studies), funded by the Dutch Ministry of Education, Culture, and Science (OCW). 


\section{APPENDIX A: REFERENCES TO THE ANALYZED CURRICULUM DOCUMENTS}

In Table VII we provide the online sources for all curriculum documents used in our research.

TABLE VII. List of websites containing the curriculum documents.

\begin{tabular}{|c|c|}
\hline Country & Curriculum document (Websites were accessed in the period 01-01-2018 to 11-11-2018) \\
\hline UK (England) & $\begin{array}{l}\text { English Office of Qualifications and Examinations Regulation. (2017). GCE subject level conditions and } \\
\text { requirements for science (biology, chemistry, and physics). Retrieved from https://assets.publishing } \\
\text {.service.gov.uk/government/uploads/system/uploads/attachment_data/file/600864/gce-subject-level- } \\
\text { conditions-and-requirements-for-science.pdf AQA Education. (2017). AS and A-level physics. } \\
\text { Retrieved from https://filestore.aqa.org.uk/resources/physics/specifications/AQA-7407-7408-SP- } \\
\text { 2015.PDF }\end{array}$ \\
\hline UK (Scotland) & $\begin{array}{l}\text { Scottish Qualifications Authority. (2015). Advanced higher physics Course/Unit support notes. Retrieved } \\
\text { from https://www.sqa.org.uk/files_ccc/AHCUSNPhysics.pdf }\end{array}$ \\
\hline Netherlands & $\begin{array}{l}\text { National Board of Examination CvTE. (2017). Natuurkunde vwo I syllabus centraal examen } 2019 . \\
\text { Retrieved from https://www.examenblad.nl/examenstof/syllabus-2019-natuurkunde-vwo/2019/vwo/ } \\
\text { f=/natuurkunde_2_versie_vwo_2019.pdf }\end{array}$ \\
\hline International & International Baccalaureate Organization. (2014). Diploma programme physics guide: First assessment \\
\hline Baccalaureate & $\begin{array}{l}\text { 2016. Cardiff, Wales: International Baccalaureate Organization (UK) Ltd. http://www.holyheart.ca/wp- } \\
\text { content/uploads/2016/10/IB-Physics-Guide-2016.pdf }\end{array}$ \\
\hline \multirow[t]{2}{*}{ Denmark } & $\begin{array}{l}\text { Danish Ministry of Education. (06-2013). Fysik stx. Retrieved from https://www.retsinformation.dk/ } \\
\text { forms/r0710.aspx?id=152507\#Bil23 }\end{array}$ \\
\hline & $\begin{array}{l}\text { English translation (Current STX curriculum) in: The Danish Evaluation Institute. (2009). The subject of } \\
\text { Physics from an international perspective. Retrieved from https://www.eva.dk/sites/eva/files/2017-08/ } \\
\text { Physics from an international perspective.pdf }\end{array}$ \\
\hline Norway & $\begin{array}{l}\text { Norwegian Directorate for Education and Training. (valid from 01.08.2006). Physics-program subject in } \\
\text { programs for specialization in general studies (FYS1-01). Retrieved from https://www.udir.no/k106/ } \\
\text { FYS1-01?lplang=eng }\end{array}$ \\
\hline Finland & $\begin{array}{l}\text { National Board of Education. (2015). Lukion opetussuunnitelman perusteet } 2015 \text { (the basics curriculum } \\
\text { 2015) 5.9 fysiikka. Retrieved from http://www.oph.fi/download/ } \\
\text { 172124_lukion_opetussuunnitelman_perusteet_2015.pdf } \\
\text { Older version in English: Finnish National Board of Education. (valid from 01-08-2005). National core } \\
\text { curriculum for general upper secondary education. Retrieved from http://www.oph.fi/download/ } \\
\text { 47678_core_curricula_upper_secondary_education.pdf }\end{array}$ \\
\hline Germany & $\begin{array}{l}\text { The Standing Conference of the Ministers of Education and Cultural Affairs of the Länder in the Federal } \\
\text { Republic of Germany. (2004). Einheitliche Prüfungsanforderungen in der Abiturprüfung Physik. } \\
\text { Retrieved from https://www.kmk.org/fileadmin/veroeffentlichungen_beschluesse/1989/1989_12_01- } \\
\text { EPA-Physik.pdf }\end{array}$ \\
\hline Germany (Baden & Ministry of Culture, Youth and Sports Baden-Württemberg. (2016). Bildungsplan des Gymnasiums \\
\hline Württemberg) & $\begin{array}{l}\text { Physik. Retrieved from http://www.bildungsplaene-bw.de/site/bildungsplan/get/documents/lsbw/ } \\
\text { export-pdf/depot-pdf/ALLG/BP2016BW_ALLG_GYM_PH.pdf }\end{array}$ \\
\hline $\begin{array}{l}\text { Germany } \\
\text { (Lower Saxony) }\end{array}$ & $\begin{array}{l}\text { Lower Saxony Ministry of Education. (2017). Kerncurriculum für das Gymnasium Physik. Retrieved } \\
\text { from http://db2.nibis.de/1db/cuvo/datei/ph_go_kc_druck_2017.pdf }\end{array}$ \\
\hline Germany (North & Ministry of Education of the state of North Rhine-Westphalia. (2014). Kernlehrplan für die Sekundarstufe \\
\hline Rhine-Westphalia) & $\begin{array}{l}\text { II Gymnasium/Gesamtschule in Nordrhein-Westfalen Physik. Retrieved from https://www } \\
\text {.schulentwicklung.nrw.de/lehrplaene/upload/klp_SII/ph/KLP_GOSt_Physik.pdf }\end{array}$ \\
\hline Germany (Hesse) & $\begin{array}{l}\text { Hessian Ministry of Education and Religious Affairs. (2010). Lehrplan Physik gymnasialer Bildungsgang } \\
\text { gymnasiale Oberstufe. Retrieved from https://kultusministerium.hessen.de/sites/default/files/media/go- } \\
\text { physik.pdf }\end{array}$ \\
\hline Germany (Saxony) & $\begin{array}{l}\text { Saxon State Ministry of Culture. (2011). Lehrplan Gymnasium Physik. Retrieved from https://www } \\
\text {.schule.sachsen.de/lpdb/web/downloads/lp_gy_physik_2011.pdf?v2 }\end{array}$ \\
\hline Germany (Bavaria) & $\begin{array}{l}\text { Bavarian State Institute for School Quality and Education Research ISB. (2009). Gymnasium Lehrplan für } \\
\text { Physik Jahrgangsstufe } 6 \text { bis } 12 \text {. Retrieved from http://www.isb-gym8-lehrplan.de/contentserv/3.1.neu/ } \\
\text { g8.de/index.php?StoryID=27147 }\end{array}$ \\
\hline France & $\begin{array}{l}\text { French National Ministry of education. (2014). Repères pour la formation en physique-chimie au cycle } \\
\text { terminal scientifique. Retrieved from http://cache.media.eduscol.education.fr/file/PC/45/7/ } \\
\text { reperes_formation_filiere_S_380457.pdf }\end{array}$ \\
\hline
\end{tabular}


TABLE VII. (Continued)

\begin{tabular}{|c|c|}
\hline Country & Curriculum document (Websites were accessed in the period 01-01-2018 to 11-11-2018) \\
\hline Italy (Liceo Scientifico) & $\begin{array}{l}\text { Italian Ministry of Education, University and Research. (2015). Quadro di riferimento della II prova di } \\
\text { fisica dell' esame di stato per i licei scientifici. Retrieved from http://www.miur.gov.it/il-quadro-di- } \\
\text { riferimento-della-seconda-prova-di-fisica-per-gli-esami-di-stato-dei-licei-scientifici }\end{array}$ \\
\hline Portugal & $\begin{array}{l}\text { Ministry of Education and Science. (2014). Metas curriculares de fisica } 12 .^{\circ} \text { ano curso científico- } \\
\text { humanístico de ciências e tecnologias. Retrieved from http://www.dge.mec.pt/sites/default/files/ } \\
\text { Secundario/Documentos/Documentos_Disciplinas_novo/Curso_Ciencias_Tecnologias/Fisica/ } \\
\text { metas_curriculares_fisica_12_ano.pdf }\end{array}$ \\
\hline Sweden & $\begin{array}{l}\text { Swedish National Agency for Education. Physics_aim and courses (Fysik Gymnasieprogrammen, } \\
\text { 2013). Retrieved from https://www.skolverket.se/download/18.189c87ae1623366ff374c3/ } \\
\text { 1521539980000/Physics-swedish-school.pdf }\end{array}$ \\
\hline $\begin{array}{l}\text { Germany } \\
\text { (Rhineland Palatina) }\end{array}$ & $\begin{array}{l}\text { Ministry of Education Rhineland-Palatinate. (2014). Lehrplan Physik der gymnasialen Oberstufe. } \\
\text { Retrieved from https://lehrplaene.bildung-rp.de/no-cache.html? } \\
\text { tx_pitsdownloadcenter_pitsdownloadcenter\%5Bcontroller\% } \\
\text { 5D=Download\&tx_pitsdownloadcenter_pitsdownloadcenter\%5Baction\% } \\
\text { 5D=forceDownload\&tx_pitsdownloadcenter_pitsdownloadcenter\%5Bfileid\%5D=9iBBxB07W\%2By } \\
\% \text { 2BUjfMWG5gHg\%3D\%3D }\end{array}$ \\
\hline $\begin{array}{l}\text { Belgium (Flemish } \\
\text { community) }\end{array}$ & $\begin{array}{l}\text { Flemish Confederation of Catholic Secondary Education. (2014). Fysika, derde graad ASO, leerplan } \\
\text { secundair onderwijs VVKSO. Retrieved from http://ond.vvkso-ict.com/leerplannen/doc/Fysica-2014- } \\
\text { 015.pdf }\end{array}$ \\
\hline Austria & $\begin{array}{l}\text { Austrian Federal Ministry of Education, Science and Research. (2018). Gesamte Rechtsvorschrift für } \\
\text { Lehrpläne_-allgemeinbildende höhere Schulen, Gymnasium Physik. Retrieved from https://www.ris } \\
\text {.bka.gv.at/GeltendeFassung.wxe?Abfrage=Bundesnormen\&Gesetzesnummer=10008568 Older } \\
\text { version with more details: www.physikunterricht.at—Das Portal für Physiklehrer/innen. (2004). } \\
\text { Lehrstoff physik-oberstufe. Retrieved from http://www.physikunterricht.at/Unterricht/Physik8Klasse/ } \\
\text { Lehrstoff_Oberstufe.doc }\end{array}$ \\
\hline Spain & $\begin{array}{l}\text { Ministry of Education, Culture and Sport, Spain. (2015). Real decreto 1105/2014 currículo básico de la } \\
\text { educación secundaria obligatoria y del bachillerato. Retrieved from https://www.boe.es/boe/dheisenias/ } \\
\text { 2015/01/03/pdfs/BOE-A-2015-37.pdf }\end{array}$ \\
\hline Australia & $\begin{array}{l}\text { Australian Curriculum and Assessment Reporting Authority (ACARA). (2015). Physics_-The Australian } \\
\text { Curriculum Version 7.5. Retrieved from https://www.australiancurriculum.edu.au/senior-secondary- } \\
\text { curriculum/science/physics/ or as pdf: https://www.australiancurriculum.edu.au/umbraco/Surface/ } \\
\text { Download/Pdf?subject=Physics\&type=SS }\end{array}$ \\
\hline Canada (Ontario) & $\begin{array}{l}\text { Ministry of Education. (2008). The Ontario curriculum grades } 11 \text { and } 12 \text { science. Retrieved from http:// } \\
\text { www.edu.gov.on.ca/eng/curriculum/secondary/2009science11_12.pdf }\end{array}$ \\
\hline
\end{tabular}

\section{APPENDIX B: BACKGROUND INFORMATION ABOUT EDUCATIONAL CONTEXTS}

Curriculum documents from different countries have very different structure, status, and logic; background information about courses, students and the kind of school leaving exam is important to understand the diversity of content and representation. Table VIII lists some relevant aspect of the different national educational systems.

TABLE VIII. Relevant details to understand curriculum documents in the context of each educational system.

\begin{tabular}{|c|c|c|c|c|}
\hline $\begin{array}{l}\text { Educational } \\
\text { system }\end{array}$ & $\begin{array}{l}\text { Course in which } \\
\text { QP is given }\end{array}$ & Students who may take QP & $\begin{array}{c}\text { Final exam (as part } \\
\text { of the school leaving } \\
\text { qualifications) }\end{array}$ & Additional information \\
\hline UK (England) & $\begin{array}{l}\text { "Advanced level physics" is } \\
\text { an elective two-year } \\
\text { course in the last two } \\
\text { years of secondary } \\
\text { school. }\end{array}$ & $\begin{array}{l}\text { Students preparing for } \\
\text { A-level exams in England } \\
\text { or Wales, age 17-18. }\end{array}$ & $\begin{array}{l}\text { Written A-level exam as } \\
\text { part of the school } \\
\text { leaving qualification } \\
\text { offered by the } \\
\text { educational bodies. }\end{array}$ & $\begin{array}{l}\text { The examination for } \\
\text { British A-Levels is } \\
\text { executed by } \\
\text { independent } \\
\text { examination boards }{ }^{\mathrm{a}}\end{array}$ \\
\hline
\end{tabular}


TABLE VIII. (Continued)

\begin{tabular}{|c|c|c|c|c|}
\hline $\begin{array}{l}\text { Educational } \\
\text { system }\end{array}$ & $\begin{array}{l}\text { Course in which } \\
\text { QP is given }\end{array}$ & Students who may take QP & $\begin{array}{c}\text { Final exam (as part } \\
\text { of the school leaving } \\
\text { qualifications) }\end{array}$ & Additional information \\
\hline UK (Scotland) & $\begin{array}{l}\text { "Advanced Higher Physics" } \\
\text { is an elective course in } \\
\text { the not compulsory sixth } \\
\text { year of secondary school. }\end{array}$ & $\begin{array}{l}\text { Students preparing for } \\
\text { progressing to further } \\
\text { and higher education, } \\
\text { age } 17-18 \text {. }\end{array}$ & $\begin{array}{l}\text { Written exam as part of } \\
\text { the Scottish National } \\
\text { Qualification. }\end{array}$ & $\begin{array}{l}\text { The exam is set and } \\
\text { marked by the Scottish } \\
\text { Qualifications } \\
\text { Authority (SQA). }\end{array}$ \\
\hline Netherlands & $\begin{array}{l}\text { "Natuurkunde" is an } \\
\text { elective physics course, } \\
\text { but compulsory for } \\
\text { students in the nature and } \\
\text { technology stream. }\end{array}$ & $\begin{array}{l}\text { Students attending pre- } \\
\text { university high school } \\
(v w o), \text { age } 17-18 \text {. }\end{array}$ & $\begin{array}{l}\text { Written national final } \\
\text { exam (Centraal } \\
\text { Schriftelijk VWO } \\
\text { eindexamen). }\end{array}$ & $\begin{array}{l}\text { Exams are set by a } \\
\text { national commission } \\
\text { and marked by the own } \\
\text { teacher and an } \\
\text { independent second } \\
\text { teacher. }\end{array}$ \\
\hline $\begin{array}{l}\text { Intern. } \\
\text { Baccalaureate } \\
\text { (IB) }\end{array}$ & $\begin{array}{l}\text { The Higher level (HL) } \\
\text { physics course is an } \\
\text { elective course in the } \\
\text { Diploma Programme. }\end{array}$ & $\begin{array}{l}\text { Students, preparing for the } \\
\text { pre-university IB } \\
\text { Diploma Programme, } \\
\text { age } 17-19 \text {. }\end{array}$ & $\begin{array}{l}\text { Written exam as part of } \\
\text { the IB Diploma } \\
\text { Programme. }\end{array}$ & $\begin{array}{l}\text { The written exam is } \\
\text { externally set and } \\
\text { marked. }\end{array}$ \\
\hline Denmark & $\begin{array}{l}\text { Physics (Fysik) A in is an } \\
\text { elective course in upper } \\
\text { secondary schools on } \\
\text { STX-level. }\end{array}$ & $\begin{array}{l}\text { Students attending pre- } \\
\text { university upper } \\
\text { secondary school } \\
\text { (STX or gymnasium), } \\
\text { age } 18-19 .\end{array}$ & $\begin{array}{l}\text { Oral, practical and } \\
\text { written final exams. } \\
\text { A central exam } \\
\text { commission composes } \\
\text { the written exams. }\end{array}$ & $\begin{array}{l}\text { Every year the ministry } \\
\text { of education } \\
\text { announces a theme } \\
\text { from ' } 21 \text { st century } \\
\text { physics' as part of the } \\
\text { exam. b }\end{array}$ \\
\hline Norway & $\begin{array}{l}\text { Physics }(F y s i k k) 1 \text { and } 2 \text { are } \\
\text { consecutive elective } \\
\text { courses in the upper } \\
\text { secondary school, } \\
\text { leading to higher } \\
\text { education entrance } \\
\text { qualifications. }\end{array}$ & $\begin{array}{l}\text { Physics } 1 \text { is given in grade } \\
12 \text { (students age } 17-18 \text { ) } \\
\text { and is a prerequisite for } \\
\text { the optional higher-level } \\
\text { course, given in grade } 13 \\
\text { (age 18-19). }\end{array}$ & $\begin{array}{l}\text { National written exam in } \\
\text { Physics } 2 .\end{array}$ & $\begin{array}{l}\text { Physics } 1 \text { has an oral } \\
\text { exam for a sample of } \\
\text { students each year. }\end{array}$ \\
\hline Finland & $\begin{array}{l}\text { Physics (fysiikka) 1is a } \\
\text { compulsory course. QP is } \\
\text { taught in physics } 7 \\
\text { "Matter and Radiation', } \\
\text { one of the seven elective } \\
\text { specializations in } \\
\text { physics. }\end{array}$ & $\begin{array}{l}\text { QP is taught in schools for } \\
\text { General Upper Secondary } \\
\text { Education } \\
\text { (Lukiokoulutus) which is } \\
\text { not compulsory to } \\
\text { students age 17-19. }\end{array}$ & $\begin{array}{l}\text { Students can choose to } \\
\text { take the national } \\
\text { written matriculation } \\
\text { exam for physics } \\
\text { (Ylioppilastutkinto). }\end{array}$ & $\begin{array}{l}\text { The matriculation exams } \\
\text { are executed by the } \\
\text { National Matriculation } \\
\text { Examination Board. }\end{array}$ \\
\hline Germany & $\begin{array}{l}\text { In most federal states QP is } \\
\text { part of the elective } \\
\text { physics course (Physik). } \\
\text { Students can choose } \\
\text { between two different } \\
\text { course levels. }\end{array}$ & $\begin{array}{l}\text { Students attending upper } \\
\text { pre-university secondary } \\
\text { school (Sekundarstufe II, } \\
\text { Gymnasiale Oberstufe), } \\
\text { in general, 17-19 years } \\
\text { old. Exception in } \\
\text { Bavaria. }\end{array}$ & $\begin{array}{l}\text { Students take a written } \\
\text { final exam } \\
\text { (Abiturprüfung). In } \\
\text { some states, students } \\
\text { can choose to do an } \\
\text { additional oral exam. }\end{array}$ & $\begin{array}{l}\text { The written exams are } \\
\text { federally set in } 15 \text { of } \\
\text { the } 16 \text { states. In } \\
\text { Rhineland-P., the } \\
\text { written exams are } \\
\text { locally set but still } \\
\text { under strict federal } \\
\text { control. }\end{array}$ \\
\hline France & $\begin{array}{l}\text { Chemistry and Physics } \\
\text { (Physique-Chimie) in } \\
\text { French upper secondary } \\
\text { schools is an elective } \\
\text { course. }\end{array}$ & $\begin{array}{l}\text { Students following the } \\
\text { science stream in the } \\
\text { pre-university upper } \\
\text { secondary school (lycée } \\
\text { général), age 16-18. }\end{array}$ & $\begin{array}{l}\text { Written national final } \\
\text { exam "Baccalauréat } \\
\text { général série } \\
\text { scientifique". }\end{array}$ & $\begin{array}{l}\text { The course Physique- } \\
\text { Chimie contains items } \\
\text { that in other countries } \\
\text { would be in the } \\
\text { chemistry curriculum. }\end{array}$ \\
\hline
\end{tabular}


TABLE VIII. (Continued)

\begin{tabular}{|c|c|c|c|c|}
\hline $\begin{array}{l}\text { Educational } \\
\text { system }\end{array}$ & $\begin{array}{l}\text { Course in which } \\
\text { QP is given }\end{array}$ & Students who may take QP & $\begin{array}{c}\text { Final exam (as part } \\
\text { of the school leaving } \\
\text { qualifications) }\end{array}$ & Additional information \\
\hline $\begin{array}{l}\text { Italy (Liceo } \\
\text { Scientifico) }\end{array}$ & $\begin{array}{l}\text { Physics (Fisica) is a } \\
\text { compulsory subject in } \\
\text { Liceo Scientifico, a form } \\
\text { of upper secondary } \\
\text { school, specialized in } \\
\text { science subjects. QP is } \\
\text { taught in the fifth and } \\
\text { final year of upper } \\
\text { sec.school. }\end{array}$ & $\begin{array}{l}\text { Students in final year of the } \\
\text { pre-university secondary } \\
\text { school with a focus on } \\
\text { science (Liceo scientific), } \\
\text { age } 18-19 \text {. }\end{array}$ & $\begin{array}{l}\text { Oral or teacher-set } \\
\text { written final exams } \\
\text { (Esame di Stato) are } \\
\text { common. A national } \\
\text { written final exam } \\
\text { (seconda prova) is } \\
\text { possible. }\end{array}$ & $\begin{array}{l}\text { The Ministry of } \\
\text { Education announces } \\
\text { every year if the } \\
\text { seconda prova is in } \\
\text { mathematics or } \\
\text { physics. }\end{array}$ \\
\hline Portugal & $\begin{array}{l}\text { The elective physics } \\
\text { course }(\text { Física }){ }^{\mathrm{f}}\end{array}$ & $\begin{array}{l}\text { Students in grade } 12 \text { of the } \\
\text { science and technology } \\
\text { track of pre-university } \\
\text { upper secondary school } \\
\text { (Científico-humanístico), } \\
\text { age 17-18. }\end{array}$ & $\begin{array}{l}\text { For physics, there are } \\
\text { oral examinations and } \\
\text { locally set written } \\
\text { exams. }\end{array}$ & $\begin{array}{l}\text { In lower years physics } \\
\text { and chemistry form an } \\
\text { integrated subject. }\end{array}$ \\
\hline Sweden & $\begin{array}{l}\text { Physics (Fysik) } 2 \text { and } 3 \\
\text { are consecutive elective } \\
\text { courses in the not } \\
\text { compulsory upper } \\
\text { secondary school } \\
(\text { Gymnasieskola) }\end{array}$ & $\begin{array}{l}\text { Students following a } \\
\text { national university } \\
\text { preparatory program for } \\
\text { natural sciences or } \\
\text { technology, age } 17-19 .\end{array}$ & $\begin{array}{l}\text { There is no external } \\
\text { centrally set exam for } \\
\text { physics. Teachers } \\
\text { follow an official } \\
\text { curriculum and } \\
\text { grading system. }\end{array}$ & $\begin{array}{l}\text { For physics } 2 \text {, teachers } \\
\text { can voluntarily use an } \\
\text { exam provided by the } \\
\text { Swedish National } \\
\text { Agency for Education. }\end{array}$ \\
\hline $\begin{array}{l}\text { Belgium } \\
\text { (Flemish com.) }\end{array}$ & $\begin{array}{l}\text { An optional module in the } \\
\text { elective physics course } \\
\text { (Fysica) in the final year } \\
\text { of general secondary } \\
\text { education. The physics } \\
\text { teacher decides if this } \\
\text { module is given. }\end{array}$ & $\begin{array}{l}\text { Students, who are attending } \\
\text { pre-university secondary } \\
\text { schools }(A S O), \\
\text { age } 17-18 \text {. }\end{array}$ & $\begin{array}{l}\text { All exams (oral or } \\
\text { written) are organized } \\
\text { locally on school level. }\end{array}$ & $\begin{array}{l}\text { The structure of Belgium } \\
\text { secondary education } \\
\text { yields a several } \\
\text { variations of } \\
\text { curricula. }^{\mathrm{g}}\end{array}$ \\
\hline Austria & $\begin{array}{l}\text { The elective course Physics } \\
\text { (Physik) in upper } \\
\text { secondary schools. }\end{array}$ & $\begin{array}{l}\text { Students attending pre- } \\
\text { university secondary } \\
\text { schools }(A H S \text { or } B H S) \text {, } \\
\text { age } 17-19 .\end{array}$ & $\begin{array}{l}\text { The written final exam } \\
\text { for physics is locally } \\
\text { set according to } \\
\text { national guidelines. } \\
\text { Students can choose to } \\
\text { take oral exams. }\end{array}$ & $\begin{array}{l}\text { While the written exam is } \\
\text { set by the own teacher, } \\
\text { the grading has to be } \\
\text { confirmed centrally. }\end{array}$ \\
\hline Spain & $\begin{array}{l}\text { The elective physics course } \\
\text { of the last year of } \\
\text { scientific high school. }\end{array}$ & $\begin{array}{l}\text { Students in the last two } \\
\text { years of high school } \\
\text { (Bachillerato) which are } \\
\text { not compulsory. }\end{array}$ & $\begin{array}{l}\text { No national written } \\
\text { school leaving exam. }\end{array}$ & $\begin{array}{l}\text { Universities require a } \\
\text { standardized higher } \\
\text { education entrance } \\
\text { exam. }\end{array}$ \\
\hline Australia & $\begin{array}{l}\text { The elective physics course } \\
\text { of Senior secondary } \\
\text { school Unit 4: } \\
\text { Revolutions in modern } \\
\text { physics. }\end{array}$ & $\begin{array}{l}\text { Students in Senior } \\
\text { Secondary School year } \\
\text { 12; students age 17-18. }\end{array}$ & $\begin{array}{l}\text { Centrally (on state } \\
\text { level) set written } \\
\text { examination. }\end{array}$ & $\begin{array}{l}\text { Each Australian state } \\
\text { writes its own } \\
\text { curriculum with about } \\
90 \% \text { of the content } \\
\text { from the national } \\
\text { Australian Physics } \\
\text { curriculum. }\end{array}$ \\
\hline
\end{tabular}


TABLE VIII. (Continued)

\begin{tabular}{|c|c|c|c|}
\hline $\begin{array}{l}\text { Educational } \\
\text { system }\end{array}$ & $\begin{array}{l}\text { Course in which } \\
\text { QP is given }\end{array}$ & Students who may take QP & $\begin{array}{c}\text { Final exam (as part } \\
\text { of the school leaving } \\
\text { qualifications) }\end{array}$ \\
\hline \multirow[t]{2}{*}{ Canada (Ontario) } & $\begin{array}{l}\text { The elective high school } \\
\text { physics course: Physics, } \\
\text { Grade } 12\end{array}$ & & \\
\hline & $\begin{array}{l}\text { University Preparation } \\
\text { SPH4U }\end{array}$ & $\begin{array}{l}\text { Students in the last year of } \\
\text { high school (grade 12), } \\
\text { age 17-18. }\end{array}$ & $\begin{array}{l}\text { No provincial or national } \\
\text { final exam in physics. }\end{array}$ \\
\hline
\end{tabular}

${ }^{a}$ United Kingdom (England): The national curriculum for upper secondary physics (GCE subject level conditions and requirements for science) is not very specific because independent examination boards execute the examination for British A-Levels. These examination boards on their term have very detailed exam syllabi to define precisely which content and what kind of questions students can expect in the written exam. The data for the comparison in Table V were taken from the specifications of the Assessment and Qualifications Alliance (AQA), the largest of the five main examination boards for British A-Levels.

More detailed information about NOS aspects in British science education can be found in the National Curriculum in England: Science Programmes of Study [98]. Since this document does not cover any aspects of our definition of QP, it has not been included in this research.

benmark: Physics A is required to include "Physics of the 21 st Century." The subject is a window to the current physics. The course will vary from year to year and the contents will be announced every year. In recent years the subjects were: medical physics, plasma physics, fusion energy, modern particle physics, astronomy. In Table V we indicate technical applications of QP as optional because it is likely that these are treated in Physics of the 21st Century.

Additionally, the core material of the curriculum must fill approx. $70 \%$ of teaching time. The last approx. 30\% must be used for optional (supplementary) subjects. Current events, such as significant natural phenomena and research findings in the media, can thus be included in the teaching.

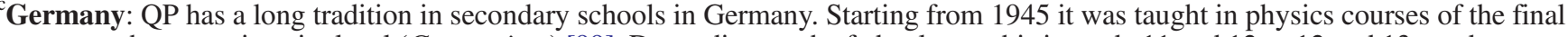
two years at the pre-university level (Gymnasium) [99]. Depending on the federal state this is grade 11 and 12 or 12 and 13; students are usually 17- to 19-years old. Physics is an elective course of two years at these grades. Students can choose between two different levels: $\mathrm{G}$ (Grundkurs), a more basic general physics course or L (Leistungskurs), a specialized course which typically has more lesson time, offers more depth, and might require a high level of mathematics. QP is a compulsory part of both courses but offered with different depth and mathematical complexity.

In Germany, a general national examination document (Einheitliche Prüfungsordnung, 2004) gives overall learning objectives. Within the guidelines of this national document, each of the 16 federal states is responsible for the school system of the individual state, examination, and related detailed syllabuses (Lehrplan). Since all states have to comply with the same national directive, they show many similarities, but still, there are significant regional differences regarding examinations, chosen topics and intended learning outcomes. To give a representative overview of Germany's variety of curricular documents we took into account the individual curricula of the seven most populated German states.

The curriculum of Bavaria has a notable specialty: students in this federal-state already learn some central QP concepts at the age of 15 . At that age, physics is a compulsory subject for all Gymnasium (pre-university secondary school) students. The developers of this curriculum consider QP as so crucial for our modern worldview that every student-even if they do not choose physics in their final years-should know some fundamental properties of QP [99].

${ }^{\mathrm{d}}$ France: Chemistry and Physics are integrated into one subject in French upper secondary schools, and there is a national curriculum for this subject. While aspects of QP were taught in French upper secondary schools before 1995, this topic disappeared in a curriculum reform. In the curriculum from 1995 selected items were more real-world related and less mathematical, and as a consequence, QP was not mentioned anymore in the intended learning outcomes [100]. However, in 2012 several QP items were reintroduced in the national curriculum [101].

${ }^{\mathrm{e}}$ Italy: The final exam on a Liceo scientifico consists of three written and one oral exam, only the first two written exams are national exam: one in Italian language and the second one in mathematics or physics. In the beginning of each year the Ministry of Education announces which of the two subjects will be examined in the national exam of that year.

${ }^{\mathrm{f}}$ Portugal: In Portugal, physics and chemistry are taught as a combined subject for higher years of secondary school (students age 15 to 18). Physics can only be chosen as a separate subject in the final year (grade 12) of the science and technology upper secondary academic track. The connection between the two subjects is intense, and QP items related to atomic models and the periodic table (e.g., the Pauli exclusion principle) are taught in chemistry lessons. Consequently, this is not visible in the comparison of physics curriculum documents of Table V.

${ }^{\mathrm{g}}$ Belgium: We analyzed the curriculum of the senior secondary general education (ASO) of the Catholic Education Flanders (VVKSO) 3, which is the largest school board in Belgium. Belgium has a complex structure of the educational system. First of all, there are three different language communities (Flemish, French, and German-speaking) with different educational systems and, second, three different school boards have their own curriculum and school leaving exam. QP is one of eight possible choice modules. The teacher chooses at least two of these modules in the last two years of secondary school.

${ }^{\mathrm{h}}$ Spain: Spanish upper secondary schools do not have a high stakes leaving exam. However, students who want to enter university have to take a national university entrance test (Prueba de Acceso a la Universidad, PAU), which can be regarded as equivalent to final exams in other countries. These PAU exams are set by the Public Universities, and the content of the exam is not exactly the same as the high school curriculum. During recent years there have not been any questions about QP in the PAU. In practice, this can make QP to an underestimated topic in high school, and teachers occasionally skip it in order to have more lesson time for tested topics [102]. 


\section{APPENDIX C: EXAMPLES OF CURRICULUM TEXTS CONCERNING NOS ASPECT N2: THE ROLE OF SCIENTIFIC MODELS}

To illustrate the variety of curriculum documents, we provide examples that show how the role of scientific models is described in some countries.

Denmark (Current STX curriculum-Physics B)

"Through their work with experiments and theoretical models, the pupils will gain knowledge of how physics models are set up and used as a means to qualitatively and quantitatively explain phenomena and processes". (Purpose, p. 55)

Italy (Framework of the Second Physics exam of the State Exam for the Licei Scientifici, translated by the author)

"[At the end of the high school career the student will have the following general competencies:]

- Being able to examine a physical situation by formulating explanatory hypotheses through models or analogies or laws; ...

- Being able to interpret and/or process data, also of an experimental nature, verifying their relevance to the chosen model. ..." (General competences of Physics, p. 3)

Lower Saxony, Germany I (Core curriculum for upper secondary Gymnasium education, Physics)

"Working with models

Physical problems are made accessible by modeling and certain idealizations of processes. Models can be representational, iconic, graphical or mathematical or they use analogies. Examples from lower secondary education are the core-shell model of the atom, the model of elementary magnets and the particle model introduced in chemistry classes as iconic models, energy flow diagrams as graphic models. In upper secondary education, mathematical models also include phasor diagrams. In examples, the students recognize the capacity of models to make predictions and they understand the limits of models. Only advanced learners are able to reflect on the differences between model and reality."

At the end of lower secondary education, the students ...

- show relationships in the form of graphical representations.

- check hypotheses on selected examples by self-designed experiments.

- use models as a tool for solving problems and formulating hypotheses.

- describe idealizations in different situations.

- distinguish between models and reality.

Additionally, at the end of upper secondary education, the students ...

- represent relationships in the form of function equations.

- only advanced level: model simple processes with differential equations.
- explain the model of the potential well and use it as a heuristic tool for problem solving.

- Use the phasor representation or other appropriate representation to solve problems in wave physics or quantum physics.

- recognize structural equalities and use them to transfer existing knowledge to other situations.

- distinguish between model presentation, iconic representation and reality."

(Process related competencies, p. 19, translated from German)

England (AQA Education, specifications AS and Alevel physics)

"Understanding of How Science Works is a requirement ... and is set out in the following points which are taken directly from the GCE AS and A Level subject criteria for science subjects. Each point is expanded in the context of Physics. The specification references given illustrate where the example is relevant and could be incorporated.

A. Use theories, models and ideas to develop and modify scientific explanations

Scientists use theories and models to attempt to explain observations. These theories or models can form the basis for scientific experimental work.

Scientific progress is made when validated evidence is found that supports a new theory or model.

Candidates should use historical examples of the way scientific theories and models have developed and how this changes our knowledge and understanding of the physical world.

Examples in this specification include

- Galileo deduced from his inclined plane experiment that falling objects accelerate. Newton later explained why and showed that freely-falling objects have the same acceleration. The kinetic theory of gases explains the experimental gas laws."

(How Science Work, p. 36-37)

Australia (ACARA | The Australian Curriculum | Version 7.5)

"Physics uses qualitative and quantitative models and theories based on physical laws to visualise, explain and predict physical phenomena. Models, laws, and theories are developed from, and their predictions are tested by making, observations and quantitative measurements." (Rationale, p. 4)

"Physics aims to develop students' understanding of the ways in which models and theories are refined and new models and theories are developed in physics; and how physics knowledge is used in a wide range of contexts and informs personal, local and global issues." (Aims, p. 4)

"As science involves the construction of explanations based on evidence, the development of science concepts, models and theories is dynamic and involves critique and uncertainty. Science concepts, models and theories 
are reviewed as their predictions and explanations are continually re-assessed through new evidence, often through the application of new technologies." (Science as a Human Endeavour, p. 7)

"Science understanding is evident when a person selects and integrates appropriate science concepts, models and theories to explain and predict phenomena, and applies those concepts, models and theories to new situations. Models in science can include diagrams, physical replicas, mathematical representations, word-based analogies (including laws and principles) and computer simulations. Development of models involves selection of the aspects of the system/s to be included in the model, and thus models have inherent approximations, assumptions and limitations. The Science Understanding content in each unit develops students' understanding of the key concepts, models and theories that underpin the subject, and of the strengths and limitations of different models and theories for explaining and predicting complex phenomena." (Science understanding, p. 8)

"By the end of this unit, students ... understand how scientific models and theories have developed and are applied to improve existing, and develop new, technologies." (Learning outcomes, p. 13)

"For the physical systems studied, the student...

- applies theories and models of systems and processes to explain phenomena, interpret complex problems, and make reasoned, plausible predictions in unfamiliar contexts.

- analyzes the roles of collaboration, debate and review, and technologies, in the development of physical science theories and models"

(Achievement Standard A, B, and C, p. 28)

"For the physical systems studied, the student...

- identifies aspects of a theory or model related to the system; describes phenomena, interprets simple problems, and makes simple predictions in familiar contexts.

- describes the roles of communication and new evidence in developing physical science knowledge; describes ways in which physical science has been used in society to meet needs,"

(Achievement Standard D and E, p. 28)
[1] G. Pospiech, in Proceedings of the GIREP08 conference, Nicosia, Cyprus (International Research Group on Physics Teaching, 2009), https://pdfs.semanticscholar.org/ 41b6/abdd846856e7aeee55e43f9842741c96a2f9.pdf.

[2] T. Kaur, D. Blair, J. Moschilla, W. Stannard, and M. Zadnik, Teaching Einsteinian physics at schools: Part 3, review of research outcomes, Phys. Educ. 52, 065014 (2017).

[3] K. Krijtenburg-Lewerissa, H. J. Pol, A. Brinkman, and W. R. van Joolingen, Insights into teaching quantum mechanics in secondary and lower undergraduate education, Phys. Rev. ST Phys. Educ. Res. 13, 010109 (2017).

[4] B. Bungum, E. K. Henriksen, C. Angell, C. W. Tellefsen, and M. V. Bøe, ReleQuant-improving teaching and learning in quantum physics through educational design research, Nordic Studies in Science Education 11, 153 (2015).

[5] A. Johansson, Undergraduate quantum mechanics: Lost opportunities for engaging motivated students?, Eur. J. Phys. 39, 025705 (2018).

[6] C. Angell, Ø. Guttersrud, E. K. Henriksen, and A. Isnes, Physics: Frightful, but fun, Sci. Educ. 88, 683 (2004).

[7] Y. Hadzigeorgiou and S. Stivaktakis, Encouraging involvement with school science, J. Curric. Pedag. 5, 138 (2008).

[8] C. A. Fuchs and A. Peres, Quantum theory needs no 'interpretation', Phys. Today 53, No. 3, 70 (2000).

[9] N. G. van Kampen, The scandal of quantum mechanics, Am. J. Phys. 76, 989 (2008).
[10] M. Alonso, Emphasize applications in introductory quantum mechanics courses [Letter to the editor], Am. J. Phys. 70, 887 (2002).

[11] O. Levrini and P. Fantini, Encountering productive forms of complexity in learning modern physics, Sci. Educ. 22, 1895 (2013).

[12] J. R. Hoehn and N. D. Finkelstein, Students' flexible use of ontologies and the value of tentative reasoning: Examples of conceptual understanding in three canonical topics of quantum mechanics, Phys. Rev. Phys. Educ. Res. 14, 010122 (2018).

[13] G. Pospiech, Philosophy and quantum mechanics in science teaching, Sci. Educ. 12, 559 (2003).

[14] S. Klassen, The photoelectric effect: Reconstructing the story for the physics classroom, Sci. Educ. 20, 719 (2011).

[15] B. Latour, Science in Action: How to Follow Scientists and Engineers through Society (Harvard University Press, Cambridge, MA, 1987).

[16] K. Hogan, Exploring a process view of students' knowledge about the nature of science, Sci. Educ. 84, 51 (2000).

[17] W. A. Sandoval, Understanding students' practical epistemologies and their influence on learning through inquiry, Sci. Educ. 89, 634 (2005).

[18] A. Garritz, Teaching the philosophical interpretations of quantum mechanics and quantum chemistry through controversies, Sci. Educ. 22, 1787 (2013).

[19] T. Lobato and I. M. Greca, Quantum theory contents insertion in high school curricula-Análise da inserção de conteúdos de Teoria quântica nos currículos de física do 
Ensino Médio, Ciência \& Educação (Bauru) 11, 119 (2005).

[20] I. V. S. Mullis, M. O. Martin, P. Foy, and M. Hooper, TIMSS Advanced 2015 International Results in Advanced Mathematics and Physics (TIMSS \& PIRLS International Study Center Website, Boston College, 2016), http:// timssandpirls.bc.edu/timss2015/international-results/wpcontent/uploads/filebase/full\%20pdfs/T15-InternationalResults-in-Mathematics.pdf.

[21] G. Hass, Curriculum Planning: A New Approach (Allyn and Bacon, Boston, MA, 1987).

[22] J. Wiles, Leading Curriculum Development (Corwin Press, Thousand Oaks, CA, 2008).

[23] J. Van den Akker, Building bridges: How research may improve curriculum policies and classroom practices, Beyond Lisbon 2010: Perspectives from Research and Development for Educational Policy in Europe (CIDREE, Belgium, 2010), p. 175.

[24] J. Van den Akker, Curriculum Perspectives: An Introduction (Springer, Dordrecht, Netherlands, 2003), p. 1.

[25] J. Goodlad, Curriculum Inquiry. The Study of Curriculum Practice (McGraw-Hill, NY, 1979).

[26] S. Wuttiprom, M. D. Sharma, I. D. Johnston, R. Chitaree, and C. Soankwan, Development and use of a conceptual survey in introductory quantum physics, Int. J. Sci. Educ. 31, 631 (2009).

[27] H. Kragh, A sense of history: History of science and the teaching of introductory quantum theory, Sci. Educ. 1, 349 (1992).

[28] E. W. Jenkins, The 'nature of science' in the school curriculum: The great survivor, J. Curric. Stud. 45, 132 (2013).

[29] J. Holbrook and M. Rannikmae, The nature of science education for enhancing scientific literacy, Int. J. Sci. Educ. 29, 1347 (2007).

[30] R. Khishfe, Nature of science and decision-making, Int. J. Sci. Educ. 34, 67 (2012).

[31] H. A. Yacoubian, Scientific literacy for democratic decision-making, Int. J. Sci. Educ. 40, 308 (2018).

[32] W. F. McComas, M. P. Clough, and H. Almazroa, The Role and Character of the Nature of Science in Science Education (Springer, Dordrecht, Netherlands, 1998), p. 3.

[33] N. G. Lederman, Nature of science: Past, present, and future (Lawrence Erlbaum Associates, Mahwah, NJ, 2007), 2, p. 831.

[34] D. Allchin, Teaching the Nature of Science: Perspectives \& Resources (Ships Education Press, Saint Paul, MN, 2013).

[35] S. Erduran and Z.R. Dagher, Reconceptualizing the nature of science for science education: Scientific knowledge, Practices and Other Family Categories (Springer, Dordrecht, Netherlands, 2014).

[36] J. Petri and H. Niedderer, A learning pathway in highschool level quantum atomic physics, Int. J. Sci. Educ. 20, 1075 (1998).

[37] I. D. Johnston, K. Crawford, and P. R. Fletcher, Student difficulties in learning quantum mechanics, Int. J. Sci. Educ. 20, 427 (1998).

[38] F. Abd-El-Khalick, J. Y. Myers, R. Summers, J. Brunner, N. Waight, N. Wahbeh, A. A. Zeineddin, and
J. Belarmino, A longitudinal analysis of the extent and manner of representations of nature of science in U.S. high school biology and physics textbooks, J. Res. Sci. Teach. 54, 82 (2017).

[39] C. Baily and N. D. Finkelstein, Teaching quantum interpretations: Revisiting the goals and practices of introductory quantum physics courses, Phys. Rev. ST Phys. Educ. Res. 11, 020124 (2015).

[40] I. M. Greca and O. Freire, Meeting the Challenge: Quantum Physics in Introductory Physics Courses (Springer, Dordrecht, Netherlands, 2014).

[41] W. F. McComas and J. K. Olson, The Nature of Science in International Science Education Standards Documents (Springer, Dordrecht, Netherlands, 1998), p. 41.

[42] J. Osborne, S. Collins, M. Ratcliffe, R. Millar, and R. Duschl, What Ideas-about-Science should be taught in school science? A Delphi study of the expert community, J. Res. Sci. Teach. 40, 692 (2003).

[43] S. Y. Kim and K. E. Irving, History of science as an instructional context: Student learning in genetics and nature of science, Sci. Educ. 19, 187 (2010).

[44] M. P. Clough, History and Nature of Science in Science Education (Springer, New York, 2017), p. 39.

[45] G. Á Zemplén, Conflicting agendas: Critical thinking versus science education in the international baccalaureate theory of knowledge course, Sci. Educ. 16, 167 (2007).

[46] R. P. Crease, The most beautiful experiment, Phys. World 15, 17 (2002).

[47] R. P. Feynman, R. B. Leighton, and M. L. Sands, The Feynman Lectures on Physics/Vol. III, Quantum Mechanics (Addison-Wesley, Reading, MA, 1965).

[48] D. Harrison, Teaching the Tao of physics, Am. J. Phys. 47, 779 (1979).

[49] G. Pospiech, Teaching the EPR paradox at high school?, Phys. Educ. 34, 311 (1999).

[50] C. Baily, N. D. Finkelstein, C. Singh, M. Sabella, and S. Rebello, Interpretation in quantum physics as hidden curriculum, AIP Conf. Proc. 1289, 69 (2010).

[51] W. K. Adams, K. K. Perkins, N. S. Podolefsky, M. Dubson, N. D. Finkelstein, and C. E. Wieman, New instrument for measuring student beliefs about physics and learning physics: The Colorado Learning Attitudes about Science Survey, Phys. Rev. ST Phys. Educ. Res. 2, 010101 (2006).

[52] H. V. Myhrehagen and B. Bungum, 'From the cat's point of view': Upper secondary physics students' reflections on Schrödinger's thought experiment, Phys. Educ. 51, 055009 (2016).

[53] G. Pospiech, Uncertainty and complementarity: The heart of quantum physics, Phys. Educ. 35, 393 (2000).

[54] H. Heise, M. Sinzinger, Y. Struck, and R. Wodzinski, DPG-Studie zur Unterrichtsversorgung im Fach Physik und zum Wahlverhalten der Schülerinnen und Schüler (Deutsche Physikalische Gesellschaft, Bad Honnef, Germany, 2014).

[55] C. Vermeulen and M. de Boer, Examenmonitor VO 2017 (Ministerie van Onderwijs Cultuur en Wetenschap, DUO, 2017). 
[56] Verteilung der Schüler in der Jahrgangsstufe 8 (Bayerisches Landesamt für Statistik, München, 2018).

[57] T. Kaur, D. Blair, W. Stannard, D. F. Treagust, G. Venville, M. Zadnik, W. Mathews, and D. Perks, Determining the intelligibility of Einsteinian concepts with middle school students, Res. Sci. Educ. 1 (2018).

[58] T. Kaur, D. Blair, R. K. Choudhary, Y. S. Dua, A. Foppoli, D. F. Treagust, G. Venville, and M. Zadnik, Gender response to Einsteinian physics interventions in school, arXiv:1712.06323.

[59] S. McKagan, K. Perkins, and C. Wieman, Design and validation of the quantum mechanics conceptual survey, Phys. Rev. ST Phys. Educ. Res. 6, 020121 (2010).

[60] H. Fischler and M. Lichtfeldt, Modern physics and students' conceptions, Int. J. Sci. Educ. 14, 181 (1992).

[61] M. Niaz, S. Klassen, B. McMillan, and D. Metz, Reconstruction of the history of the photoelectric effect and its implications for general physics textbooks, Sci. Educ. 94, 903 (2010).

[62] J. Strnad, Photons in introductory quantum physics, Am. J. Phys. 54, 650 (1986).

[63] D. G. C. Jones, Teaching modern physics-misconceptions of the photon that can damage understanding, Phys. Educ. 26, 93 (1991).

[64] O. Passon, T. Zügge, and J. Grebe-Ellis, Pitfalls in the teaching of elementary particle physics, Phys. Educ. 54, 015014 (2019).

[65] M. A. B. Whitaker, History, and quasi-history in physics education. I, Phys. Educ. 14, 108 (1979).

[66] D. Prutchi and S. R. Prutchi, Exploring Quantum Physics through Hands-On Projects (Wiley, Hoboken, NJ, 2012).

[67] S. McKagan, W. Handley, K. Perkins, and C. Wieman, A research-based curriculum for teaching the photoelectric effect, Am. J. Phys. 77, 87 (2009).

[68] A. Kohnle, D. Cassettari, T. J. Edwards, C. Ferguson, A. D. Gillies, C. A. Hooley, N. Korolkova, J. Llama, and B. D. Sinclair, A new multimedia resource for teaching quantum mechanics concepts, Am. J. Phys. 80, 148 (2012).

[69] K. Krijtenburg-Lewerissa, H. Pol, A. Brinkman, and W. van Joolingen, Key topics for quantum mechanics at secondary schools: A Delphi study into expert opinions, Int. J. Sci. Educ. 41, 349 (2019).

[70] R. Müller and H. Wiesner, Teaching quantum mechanics on an introductory level, Am. J. Phys. 70, 200 (2002).

[71] D. Gil and J. Solbes, The introduction of modern physics: Overcoming a deformed vision of science, Int. J. Sci. Educ. 15, 255 (1993).

[72] Y. W. Cheong and J. Song, Different levels of the meaning of wave-particle duality and a suspensive perspective on the interpretation of quantum theory, Sci. Educ. 23, 1011 (2014).

[73] R. Beneduci and F. E. Schroeck, On the unavoidability of the interpretations of quantum mechanics, Am. J. Phys. 82, 80 (2014).

[74] E. Marshman and C. Singh, Investigating and improving student understanding of quantum mechanics in the context of single photon interference, Phys. Rev. Phys. Educ. Res. 13, 010117 (2017).
[75] M. Bunge, Foundations of Physics (Springer-Verlag, Berlin, 1967).

[76] P. Lautesse, A. Vila Valls, F. Ferlin, J. Héraud, and H. Chabot, Teaching quantum physics in upper secondary school in France: 'Quanton' versus 'wave-particle' duality, two approaches of the problem of reference, Sci. Educ. 24, 937 (2015).

[77] E. K. Henriksen, C. Angell, A. I. Vistnes, and B. Bungum, What is light? Students' reflections on the wave-particle duality of light and the nature of physics, Sci. Educ. 27, 81 (2018).

[78] A. Jones and C. Kirk, Introducing technological applications into the physics classroom: Help or hindrance for learning?, Int. J. Sci. Educ. 12, 481 (1990).

[79] P. J. Fensham, Real world contexts in PISA science: Implications for context-based science education, J. Res. Sci. Teach. 46, 884 (2009).

[80] R. Taconis, P. den Brok, and A. Pilot, Teachers Creating Context-Based Learning Environments in Science (Sense Publishers, Rotterdam, 2016).

[81] E. Whitelegg and C. Edwards, Beyond the LaboratoryLearning Physics Using Real-life Contexts (Kluwer Academic Publishers, Dordrecht, Netherlands, 2001), p. 337.

[82] A. Johansson, S. Andersson, M. Salminen-Karlsson, and M. Elmgren, "Shut up and calculate": The available discursive positions in quantum physics courses, Cult. Stud. Sci. Educ. 13, 205 (2018).

[83] J. Osborne and J. Dillon, Science Education in Europe: Critical reflections (The Nuffield Foundation, London, GB, 2008), 13.

[84] B. Bungum, M. V. Bøe, and E. K. Henriksen, Quantum talk: How small-group discussions may enhance students' understanding in quantum physics, Sci. Educ. 102, 856 (2018)

[85] B. Bungum, C. Angell, C. W. Tellefsen, and E. K. Henriksen, in Electronic Proceedings of ESERA 2015, Part 1: Learning science: Conceptual understanding, Helsinki, Finland, edited by J. Lavonen, K. Juuti, J. Lampiselkä, A. Uitto, and K. Hahl (2016), p. 11.

[86] E. K. Henriksen, B. Bungum, C. Angell, C. W. Tellefsen, T. Frågåt, and M. V. Bøe, Relativity, quantum physics and philosophy in the upper secondary curriculum: Challenges, opportunities and proposed approaches, Phys. Educ. 49, 678 (2014).

[87] M. Fullan, Change Forces: Probing the Depth of Educational Reform (Falmer Press, London, UK, 1993).

[88] B. C. Grau, How to teach basic quantum mechanics to computer scientists and electrical engineers, IEEE Trans. Ed. 47, 220 (2004).

[89] A. Kohnle, I. Bozhinova, D. Browne, M. Everitt, A. Fomins, P. Kok, G. Kulaitis, M. Prokopas, D. Raine, and E. Swinbank, A new introductory quantum mechanics curriculum, Eur. J. Phys. 35, 015001 (2014).

[90] W. Dür and S. Heusler, Visualization of the invisible: The qubit as key to quantum physics, Phys. Teach. 52, 489 (2014).

[91] W. Dür and S. Heusler, The qubit as key to quantum physics part II: Physical realizations and applications, Phys. Teach. 54, 156 (2016). 
[92] M. Michelini, R. Ragazzon, L. Santi, and A. Stefanel, Proposal for quantum physics in secondary school, Phys. Educ. 35, 406 (2000).

[93] C. Manogue, D. McIntyre, J. Tate, and E. Gire, Representations for a spins-first approach to quantum mechanics, AIP Conf. Proc. 1413, 55 (2012).

[94] H. Sadaghiani, in Proceedings of the 2016 Physics Education Research Conference, Sacramento, CA, edited by D. Jones, L. Ding, and A. L. Traxler (AIP, New York, 2016), p. 292.

[95] A. Pereira, F. Ostermann, and C. Cavalcanti, On the use of a virtual Mach-Zehnder interferometer in the teaching of quantum mechanics, Phys. Educ. 44, 281 (2009).

[96] A. Kohnle, C. Baily, A. Campbell, N. Korolkova, and M. J. Paetkau, Enhancing student learning of two-level quantum systems with interactive simulations, Am. J. Phys. 83, 560 (2015).
[97] A. Lopez-Incera and W. Dür, Entangle me! A game to demonstrate the principles of quantum mechanics, Am. J. Phys. 87, 95 (2019).

[98] UK Department for Education, National curriculum in England: Science programmes of study (www.gov.uk, 2015), 2018

[99] R. Müller, Qualitative Quantenphysik-Eine Handreichung für die Sekundarstufe I (IPN, Kiel, Germany, 2006).

[100] C. Crastes (private communication).

[101] Annexe: Programme de l'enseignement spécifique et de spécialité de physique-chimie, Classe Terminale de la série scientifique (Ministère de l'éducation, 2011), Bulletin officiel de l'Éducation nationale, spécial no8 du 13 octobre 2011.

[102] Á. Vázquez (private communication). 